\title{
Analisis Pembiayaan Sektor Perdagangan Hotel dan Restoran pada Perbankan Syariah di Indonesia
}

\section{Islamic Banking Financing Analysis on Trade, Hotels, and Restaurants Sector in Indonesia}

\author{
Geri Suryadi $^{1}$, Dominicus Savio Priyarsono ${ }^{2}$, Laily Dwi Arsyianti ${ }^{3}$ \\ ${ }^{1}$ Fakultas Ekonomi dan Manajemen IPB, Jl. Raya Darmaga Kampus IPB Darmaga, Bogor, \\ Email : geri.suryadi1@gmail.com \\ ${ }^{2}$ Dosen Fakultas Ekonomi dan Manajemin IPB, Jl. Raya Darmaga Kampus IPB Darmaga, \\ Bogor, Email : priyarsono@yahoo.com \\ ${ }^{2}$ Dosen Fakultas Ekonomi dan Manajemin IPB, Jl. Raya Darmaga Kampus IPB Darmaga, \\ Bogor, Email : arsyianti@gmail.com
}

\begin{abstract}
Islamic banking is an alternative for entrepreneurs in trade, hotel, and restaurants (THR) to obtain capital relief that can push the pace of economic. The purpose of this study was to analyze the response of Islamic banking financing ratios on THR sector in the event of shocks to the banking performance factors, monetary instruments, macroeconomic conditions and the rate of return and analyze the contribution of each variable in explaining the diversity of Islamic financing ratios in THR sector. The analytical method used is Vector Error Correction Model (VECM) with variables that describe the performance of banking, macroeconomic conditions, monetary instruments, and financial returns. The results showed that, shocks to the variables Industrial Production Index (IPI), lending rates (SBK) and equivalent rate financing (ERP) will be responded positively by Islamic financing ratio of THR sector. While shocks to the variables of Third Party Funds (TPF), troubled financing (NPF), a bonus SBI Sharia (BSBIS), inflation (INF) and the placement of funds in the money market with Sharia principles (PUAS) will be responded negatively by Islamic financing ratio of THR sector. Based on this research, Islamic banking should be more focus on financing for the PHR sector because it will provide a great benefit to the development of the real sector.
\end{abstract}

Keywords: Financing, Islamic Banking, THR Sector, Vector Error Correction Model (VECM)

\begin{abstract}
Abstrak. Perbankan syariah dapat dijadikan alternatif bagi pengusaha sektor perdagangan, hotel, dan restoran (PHR) untuk memperoleh bantuan permodalan sehingga dapat mendorong laju ekonomi. Tujuan penelitian ini adalah menganalisis respon rasio pembiayaan sektor PHR perbankan syariah jika terjadi guncangan pada faktor-faktor kinerja perbankan, instrumen moneter, kondisi makroekonomi dan rate of return dan menganalisis kontribusi masing-masing variabel dalam menjelaskan keragaman rasio pembiayaan sektor PHR perbankan syariah. Penelitian ini menggunakan data bulanan periode Januari 2008 hingga Desember 2013. Metode analisis yang digunakan adalah Vector Error Correction Model (VECM) dengan variabel yang menggambarkan kinerja perbankan, kondisi makro, instrumen moneter, dan return pembiayaan. Hasil penelitian menunjukkan bahwa, guncangan pada variabel Industrial Production Index (IPI), suku bunga kredit (SBK) dan equivalent rate pembiayaan (ERP) akan direspon secara signifikan positif oleh rasio pembiayaan sektor PHR. Sedangkan guncangan pada variabel Dana Pihak Ketiga (DPK), pembiayaan bermasalah (NPF), bonus SBI Syariah (BSBIS), dan inflasi (INF) akan direspon secara negatif oleh rasio pembiayaan sektor PHR. Hasil penelitian menunjukkan variabel Industrial Production Index (IPI) akan direspon secara tidak signifikan positif dan Penempatan dana pada Pasar Uang dengan Prinsip Syariah (PUAS) akan direspon secara tidak signifikan negatif.
\end{abstract}

Kata kunci: Pembiayaan, Perbankan Syariah, Sektor PHR, Vector Error Correction Model (VECM) 


\section{Pendahuluan}

Sektor perdagangan, hotel, dan restoran (PHR) termasuk dalam klasifikasi sektor tersier. Selain sektor ini, dalam klasifikasi sektor tersier terdapat sektor konstruksi, sektor pengangkutan dan komunikasi, sektor keuangan, dan sektor jasa (Kementerian Keuangan Indonesia, 2012). Sektor perdagangan, hotel dan restoran (PHR) sangat berkembang dan berpengaruh bagi perekonomian Indonesia. Hal ini dijelaskan pada Gambar 1 yang menggambarkan pertumbuhan jumlah konstribusi tiap sektor ekonomi pada klasifikasi sektor tersier terhadap total Produk Domestik Bruto (PDB) Indonesia dari tahun 2007 sampai 2013.

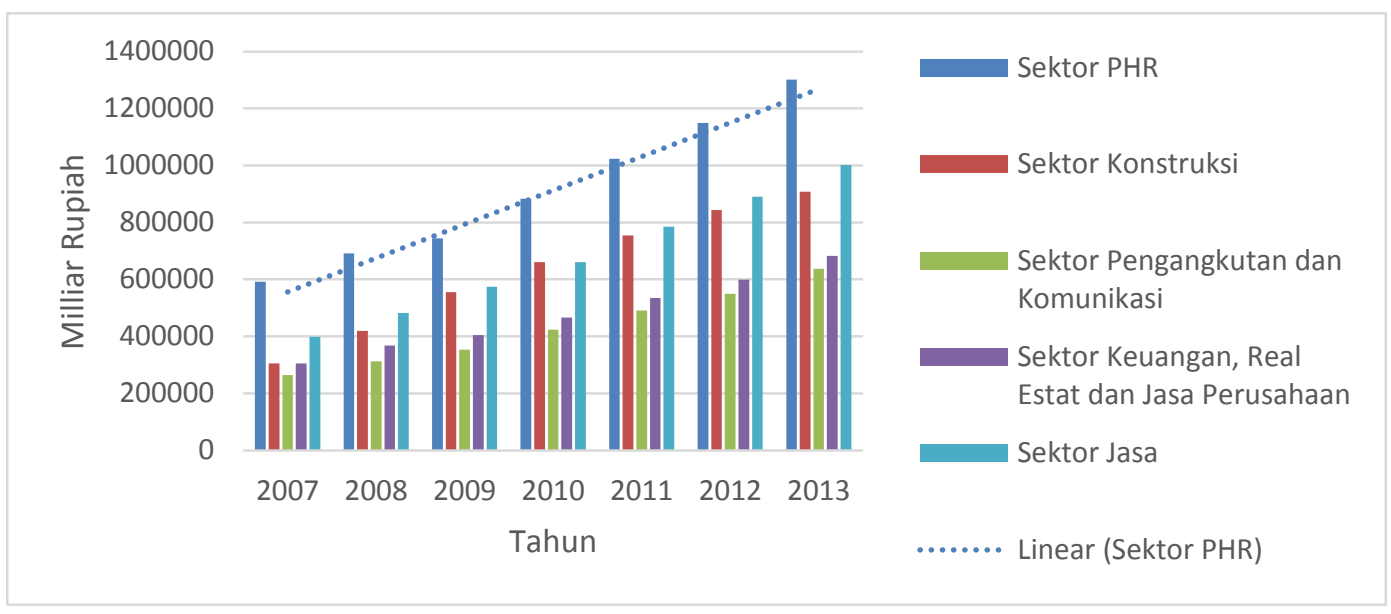

Sumber: Badan Pusat Statistik (data diolah)

Gambar 1 Perkembangan PDB Sektor PHR

Menurut Badan Pusat Statistik (BPS) 2013, sektor PHR merupakan sektor ekonomi ke-3 terbesar dalam hal memberikan konstribusi terhadap Produk Domestik Bruto (PDB) Indonesia. Sektor PHR di Indonesia memberikan kontribusi terhadap Produk Domestik Bruto (PDB) sekitar 14,32\% terhadap total PDB seluruh sektor yang berjumlah 9.083 triliun rupiah. Islam terlebih dahulu mengisyaratkan bahwa sektor PHR memiliki potensi yang besar. Potensi yang besar pada sektor PHR harus didukung oleh pemerintah, semua lapisan masyarakat, dan lembaga-lembaga yang bersangkutan, tak terkecuali lembaga keuangan perbankan. Kusumawati (2013) menyatakan bahwa perbankan merupakan lembaga keuangan yang memiliki fungsi intermediasi dalam menghimpun dana dari pihak yang kelebihan dana dan menyalurkan kembali dana tersebut pada pihak yang membutuhkan begitu pula dengan perbankan syariah. Hal ini dapat digunakan sebagai modal yang diperlukan bagi pelaku usaha di sektor PHR agar bisa menjalankan usahanya. Hal ini bertujuan agar harta tidak hanya beredar di antara golongan kaya atau surplus unit. Pada perbankan syariah sektor PHR mendapatkan porsi pembiayaan paling besar diantara sektor ekonomi lainnya. Hal ini ditunjukkan oleh tabel 1.

Tabel 1 Pembiayaan Perbankan Syariah Berdasarkan Sektor (Miliar Rupiah)

\begin{tabular}{lcccccccc}
\hline Sektor & 2006 & 2007 & 2008 & 2009 & 2010 & 2011 & 2012 & 2013 \\
\hline Pertanian & 701 & 837 & 1177 & 1331 & 1762 & 2201 & 2809 & 3119 \\
Pertambangan & 375 & 511 & 965 & 1047 & 1120 & 1733 & 2094 & 3177 \\
Perindustrian & 940 & 1371 & 1340 & 1579 & 2337 & 4077 & 5008 & 5999 \\
Listrik, gas, air & 17 & 166 & 248 & 698 & 1354 & 2381 & 3159 & 4400 \\
Konstruksi & 1637 & 2371 & 3368 & 3516 & 4194 & 5858 & 7142 & 8572
\end{tabular}




\begin{tabular}{lcccccccc}
$\begin{array}{l}\text { Perdagangan, } \\
\text { restoran, dan hotel }\end{array}$ & 3041 & 4152 & 4426 & 5000 & 7609 & 9778 & 12624 & 13972 \\
$\begin{array}{l}\text { Pengangkutan, } \\
\text { pergudangan dan }\end{array}$ & & & & & & & & \\
$\begin{array}{l}\text { komunikasi } \\
\text { Jasa dunia usaha }\end{array}$ & 1165 & 1569 & 2759 & 3349 & 3696 & 3369 & 4321 & 5446 \\
Jasa & 5458 & 8425 & 11757 & 13664 & 20233 & 25630 & 37150 & 45739 \\
sosial/masyarakat & 1456 & 1904 & 2463 & 2661 & 2975 & 4464 & 7878 & 10385 \\
Lain-lain & 5655 & 6639 & 9693 & 14042 & 22902 & 43164 & 65319 & 78430 \\
Total & 20445 & 27944 & 38195 & 46886 & 68181 & 102655 & 147505 & 179239 \\
\hline
\end{tabular}

Sumber : Statistik Perbankan Syariah Bank Indonesia (2012)

Kusumawati (2013) menjelaskan perbankan syariah dapat menawarkan pembiayaan yang menguntungkan bagi sektor konstruksi karena perbankan syariah memiliki keunggulan dibandingkan bank konvensional yaitu dengan hilangnya beban bunga yang berkesinambungan dan menggantinya dengan sistem profit loss sharing begitu pula dengan sektor PHR. Sistem bagi hasil dapat mengurangi beban para pengusaha sektor PHR karena adanya pembagian resiko antara pihak bank dan nasabah peminjam sehingga perbankan syariah dapat dijadikan alternatif bagi pengusaha sektor konstruksi untuk memperoleh bantuan permodalan dalam rangka mendorong laju ekonomi (Gambar 2).

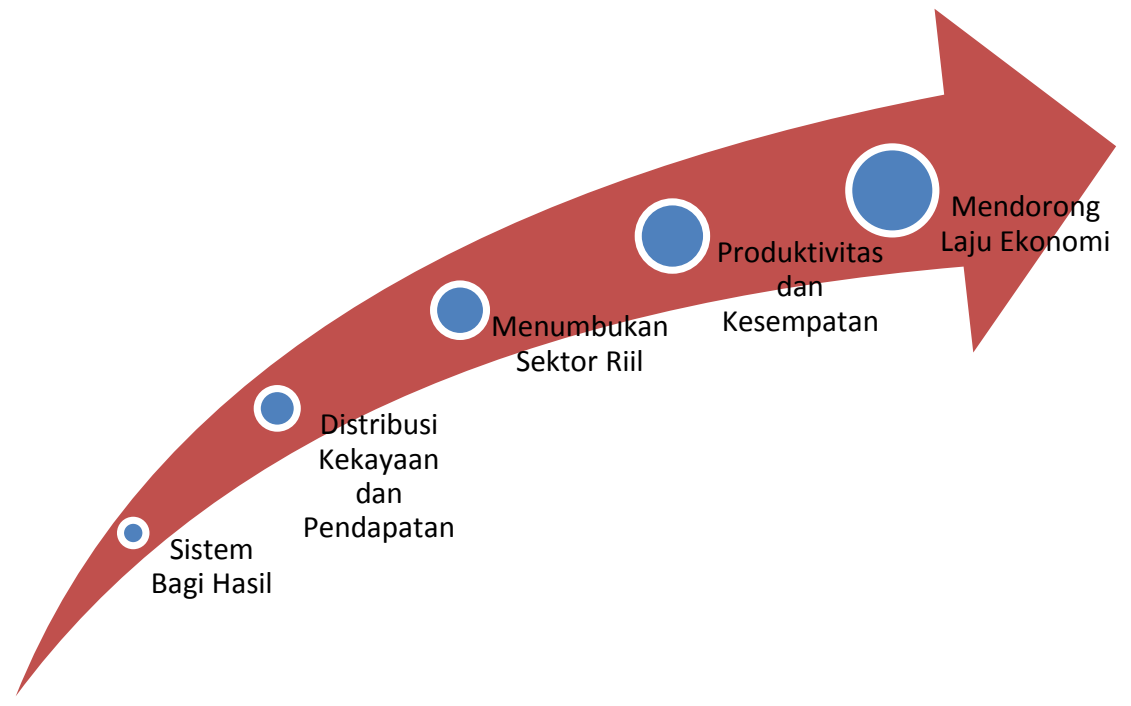

Sumber: Ascarya (2008)

\section{Gambar 2 Sistem bagi hasil pada perbankan syariah}

Ascarya (2011) menjelaskan bahwa pembagian risiko antara pihak bank dan nasabah dalam sistem bagi hasil dapat mengurangi beban para pengusaha sehingga pembiayaan syariah dapat dijadikan alternatif dalam permodalan usahanya untuk mendorong laju ekonomi. Berdasarkan produk keuangan yang dihasilkan, perbankan syariah memiliki jenis pembiayaan yang lebih beragam dibandingkan dengan perbankan konvensional. Hal ini memberikan pilihan yang beragam bagi pengusaha pada sektor PHR untuk mendapatkan bantuan modal. Data outlook perbankan syariah 2014 menyatakan bahwa peningkatan jumlah dana pihak ketiga (DPK) dan jumlah pembiayaan yang diberikan perbankan syariah mengalami peningkatan sebesar 18\% dan $17.7 \%$ dari tahun 2012 
sampai tahun 2013. Peningkatan jumlah DPK dan jumlah total pembiayaan yang disalurkan oleh perbankan syariah bisa dilihat pada Gambar 3.

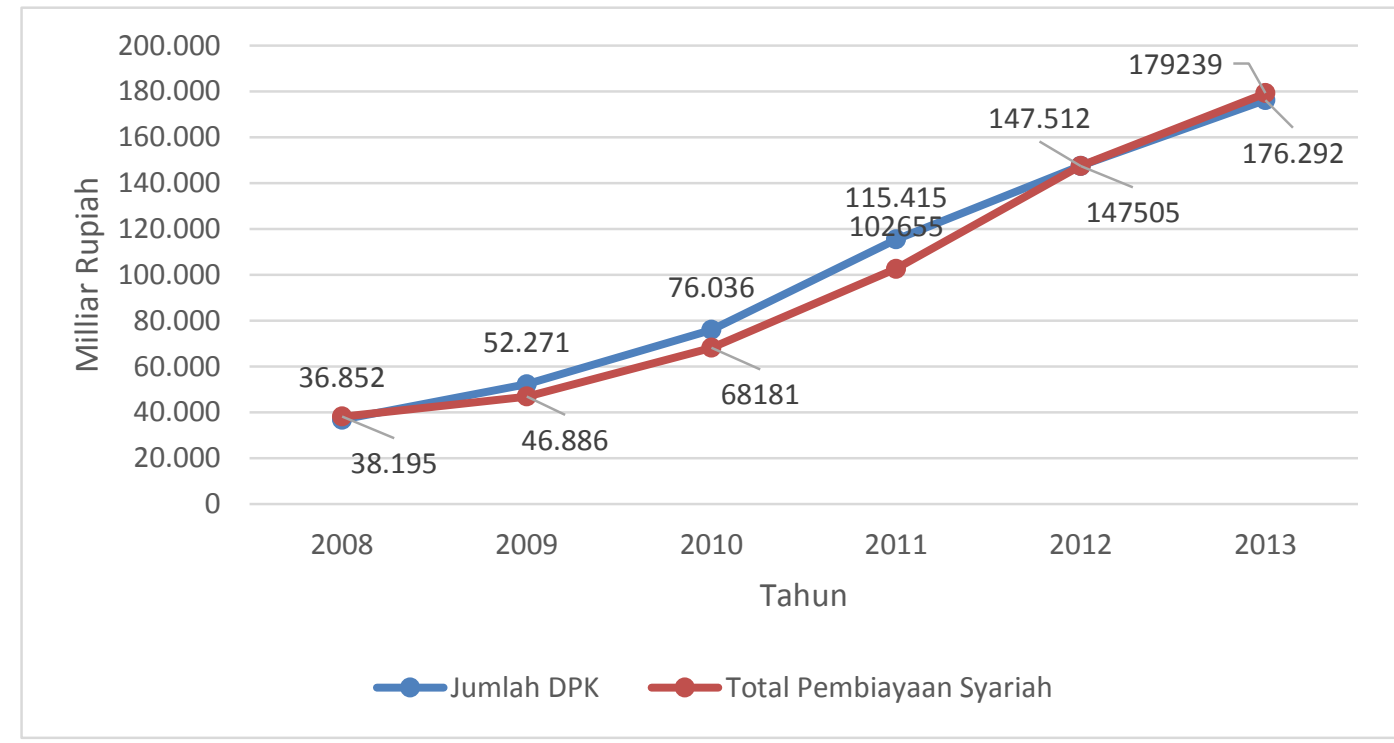

Sumber: Bank Indonesia (diolah)

Gambar 3 Perkembangan DPK dan Total Pembiayaan Perbankan Syariah

Peningkatan jumlah DPK dan pembiayaan yang disalurkan oleh bank umum syariah (BUS) dan unit usaha syariah (UUS) tidak diikuti dengan peningkatan rasio pembiayaan untuk sektor PHR terhadap total pembiayaan seluruh sektor. Menurut data statistik perbankan syariah Bank Indonesia (SPS-BI), presentase rasio pembiayaan syariah disektor PHR yang diberikan bank umum syariah (BUS) dan unit usaha syariah (UUS) cenderung mengalami penurunan dari tahun 2008 - 2013. Hal ini menunjukkan bahwa total pembiayaan yang pesat belum diikuti pertumbuhan pembiayaan pada sektor PHR, padahal sektor ini mencerminkan sektor rill. Dengan demikian, hal ini perlu mendapat perhatian dan perlu ditinjau lebih jauh.

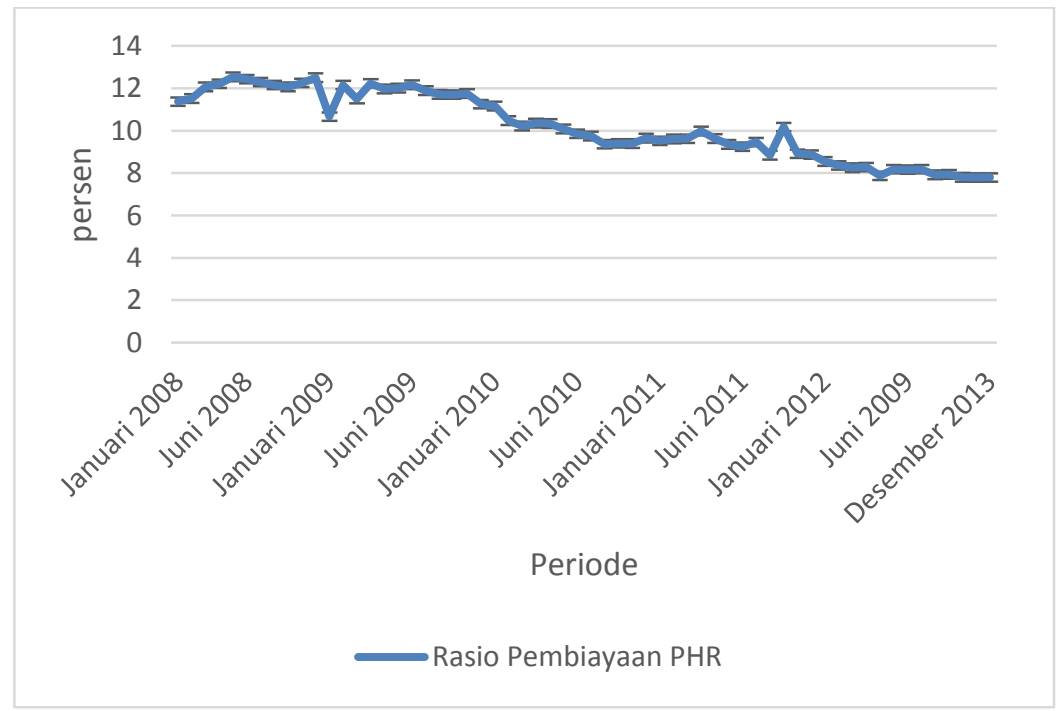

Sumber : Statistik Perbankan Syariah (diolah)

\section{Gambar 4 Perkembangan Rasio Pembiayaan PHR}


Kusumawati (2013) membagi faktor-faktor yang memengaruhi pembiayaan pada perbankan syariah menjadi 4 kategori yaitu kategori kinerja perbankan syariah dengan variabel Dana Pihak Ketiga (DPK), Financing to Deposit Ratio (FDR) dan Non Performing Financing (NPF), kategori kondisi makro dengan variabel Industrial Production Index (IPI) dan tingkat Inflasi (INF), kategori instrumen moneter dengan variabel Bonus Sertifikat Bank Indonesia Syariah (SBIS), Suku Bunga Sertifikat Bank Indonesia (SBI) dan volume penempatan pada Pasar Uang Antarbank Syariah (PUAS), dan kategori return pembiayaan dengan variabel Equivalent rate (ERP) dan Suku Bunga Kredit (SBK).

Berdasarkan rumusan masalah inilah maka tujuan dilakukannya penelitian ini antara lain:

1. Menganalisis respon rasio pembiayaan sektor PHR perbankan syariah jika terjadi guncangan pada faktor-faktor kategori kinerja perbankan, kategori instrumen moneter, kategori kondisi makroekonomi dan kategoori rate of return.

2. Mengidentifikasi konstribusi masing-masing variabel dalam menjelaskan keragaman rasio pembiayaan sektor PHR perbankan syariah.

Adapun ruang lingkup penelitian ini dibatasi hanya untuk pembiayaan pada sektor perdagangan, hotel dan restoran. Ruang lingkup perbankan syariah yang diteliti dibatasi pada Bank Umum Syariah (BUS) dan Unit Usaha Syariah (UUS), tanpa menyertakan data dari Bank Pembiayaan Rakyat Syariah (BPRS). Keterbatasan data publikasi perbankan syariah yang tersedia untuk pembiayaan sektoral, menyebabkan penelitian ini menggunakan data bulanan dengan periode dari Januari 2008 sampai dengan Desember 2013.

\section{Tinjauan Pustaka}

\subsection{Perdagangan dalam Islam}

Secara Terminologi jual beli berarti al-bai yang berarti menjual, mengganti, dan menukar sesuatu dengan sesuatu yang lain. Menurut Hanafiah pengertian jual beli (al-bai) secara definitive yaitu tukar menukar harta benda dengan sesuatu yang diinginkan dengan sesuatu yang sepadan melalui cara tertentu yang bermanfaat. Menurut Kompilasi Hukum Ekonomi Syariah (1991), al-bay adalah jual beli antara benda dengan benda, atau pertukaran antara benda dengan uang.

Menurut Kompilasi Hukum Ekonomi Syariah (1991), rukun jual beli adalah :

a) Pihak-pihak, yang terdiri dari penjual, pembeli, dan pihak lain yang terlibat

b) Objek jual beli, baik benda yang terwujud maupun yang tidak terwujud, bergerak maupun tidak bergerak

c) Kesepakatan, baik lewat lisan, tulisan, maupun isyarat

Islam pun telah mengatur hukum yang menjadi dasar dari jual beli melalui firman Allah (Q.S Al-Baqarah (2) : 275) "Dan Allah menghalalkan jual beli dan mengharamkan riba". Allah pun berfirman (Q.S An-Nisa : 29) "Hai orang-orang yang beriman janganlah kamu saling memakan harta sesamamu dengan jalan yang batil, kecuali dengan jalan perniagaan yang berlaku dengan suka sama-suka di antara kamu, dan jangalah kamu membunuh dirimu". Selain Al-Quran, Al-Hadist juga menjadi sumber hukum pada perdagangan. Rasullulah bersabda (HR. Ahmad dan Ibnu Majah) "Sesungguhnya jual beli itu atas dasar saling ridha" dan juga menurut HR. Ahmad dan Baihaqi yang menunjukkan kedudukan perdagangan di mata agama Islam yaitu "Rasullullah pun bersabda "Pekerjaan terbaik adalah usaha seseorang dengan tangannya sendiri dan semua perjualbelian yang dianggap baik ". 


\subsubsection{Pengertian Perdagangan}

Sektor perdagangan besar dan eceran meliputi kegiatan ekonomi/lapangan usaha di bidang perdagangan besar dan eceran dari berbagai jenis barang, dan memberikan imbalan jasa dari penjualan barang-barang tersebut. Yang dimaksud dengan perdagangan adalah kegiatan ekonomi yang melakukan kegiatan pengumpulan dan penjualan kembali (tanpa perubahan bentuk), barang-barang baru maupun bekas. Pedagang adalah perorangan atau badan usaha yang melakukan kegiatan perniagaan/perdagangan secara terus menerus dengan tujuan mencari keuntungan (Kementerian Keuangan Republik Indonesia,2012).

Perdagangan terbagi dalam 2 (dua) jenis yaitu :

a) Perdagangan besar, dan

b) Perdagangan eceran (ritel)

Sementara menurut fungsi dan ruang lingkup usahanya, pedagang dibedakan atas :

a) Pedagang antar daerah,

b) Pedagang antar pulau,

c) Pedagang pengumpul

d) Pedagang kaki lima

\subsubsection{Perdagangan Besar}

Kementerian Keuangan Republik Indonesia (2012) menyatakan bahwa perdagangan besar (wholesale) adalah kegiatan perdagangan dari tangan produsen atau importir, pada umumnya dalam partai besar kepada pedagang eceran, perusahaan industri, rumah sakit, usaha penyediaan akomodasi dan penyediaan makan minum, maupun kepada pedagang besar lainnya. Perdagangan besar tidak menjual barang dagangan kepada konsumen rumah tangga. Pedagang besar adalah perorangan atau badan usaha yang bertindak atas nama sendiri, dan atau nama pihak lain yang menunjuknya untuk menjalankan kegiatan dengan cara membeli, menyimpan dan menjual barang dalam partai besar.

Pedagang besar (wholesaler) terdiri dari :

a) distributor utama adalah perantara yang melakukan fungsi dalam menyalurkan barangbarang

b) dari produsen ke konsumen

c) perkulakan/grosir,

d) subdistributor,

e) pemasok besar/main supplier adalah perusahaan yang secara teratur melengkapi perusahaan lain dengan barang-barang, bahan baku, atau jasa-jasa. Usaha pemasok meliputi semua kegiatan yang berkaitan dengan penjualan barang atau jasa kepada mereka yang membeli dengan tujuan untuk menjualnya kembali atau digunakan dalam bisnis mereka. Sumber barang berasal dari hasil produksi sendiri atau dari pabrik lain.

f) dealer besar,

g) agen tunggal pemegang merk adalah perorangan atau badan usaha yang ditunjuk untuk dan atas nama pabrik pemilik merek barang tertentu untuk melakukan penjualan dalam partai besar barang dari pabrik tersebut, termasuk agen pemegang lisensi

h) eksportir adalah perusahaan perdagangan yang melaksanakan kegiatan perdagangan ekspor.

i) importir adalah perusahaan yang melakukan kegiatan perdagangan dengan cara memasukkan barang dari luar negeri ke dalam wilayah pabean Indonesia dengan memenuhi ketentuan yang berlaku/perusahaan-perusahaan berbadan hukum, yang telah memenuhi ketentuan-ketentuan Departemen Perdagangan yaitu harus memiliki API (Angka Pengenal Impor) atau APIS (Angka Pengenal Impor Sementara) atau APIT (Angka Pengenal Impor Terbatas). 


\subsubsection{Perdagangan Eceran}

Kementerian Keuangan Republik Indonesia (2012) menyatakan bahwa perdagangan eceran (ritel) adalah kegiatan perdagangan yang umumnya melayani konsumen rumah tangga atau konsumen perorangan. Perdagangan eceran dibagi 2 jenis yaitu:

1. Swalayan, terbagi dalam :

a. Supermarket merupakan unit kegiatan perdagangan eceran berskala besar, biasanya menjual makanan/minuman, bahan makanan/minuman dan tembakau dari berbagai merek yang bervariasi dengan harga yang sudah tetap atau fixed price, dan harga yang relatif murah bila dibandingkan dengan tempat perdagangan biasa

b. Department store/toserba merupakan usaha perdagangan yang berskala besar dan lengkap dengan aneka barang dagangan, seperti barang-barang yang khusus yang utamanya adalah bukan makanan/minuman, perlengkapan pakaian, barang pecah belah, perlengkapan rumah tangga dan alat kantor.

2. Bukan swalayan, misalnya toko/kios adaah usaha perdagangan yang khusus memperdagangkan komoditi yang sejenis, yang terdiri dari komoditi makanan, minuman dan tembakau dari hasil industri pengolahan dan komoditi bukan makanan, minuman dan tembakau.

Pedagang pengecer adalah perorangan atau badan usaha yang kegiatan pokoknya melakukan penjualan secara langsung kepada konsumen akhir dalam partai kecil.

\subsection{Pengertian Hotel}

Hotel adalah suatu jenis akomodasi yang mempergunakan sebagian atau seluruh bangunan untuk menyediakan jasa pelayanan penginapan, makan dan minum serta jasa lainnya bagi umum, yang dikelola secara komersial serta memenuhi ketentuan persyaratan yang ditetapkan di dalam Keputusan Pemerintah (Kementerian Keuangan Republik Indonesia, 2012).

Hotel berbintang adalah usaha yang menggunakan suatu bangunan atau sebagian bangunan yang disediakan secara khusus, dimana setiap orang dapat menginap, makan, serta memperoleh pelayanan dan fasilitas lainnya dengan pembayaran dan telah memenuhi persyaratan sebagai hotel berbintang.

Ciri khusus dari hotel adalah mempunyai restoran yang berada dibawah manajemen hotel tersebut. Persyaratan tersebut antara lain mencakup:

a) Persyaratan fisik seperti lokasi hotel, kondisi bangunan

b) Bentuk pelayanan yang diberikan (service)

c) Kualifikasi tenaga kerja seperti pendidikan dan kesejahteraan karyawan

d) Fasilitas olahraga dan rekreasi lainnya yang tersedia, seperti lapangan tenis, kolam renang dan diskotik

e) Jumlah kamar yang tersedia

Hotel berbintang dapat dibedakan menjadi 5 (lima) yaitu:

a) Hotel bintang 5

b) Hotel bintang 4

c) Hotel bintang 3

d) Hotel bintang 2

e) Hotel bintang 1

Hotel melati adalah usaha yang menggunakan suatu bangunan atau sebagian bangunan yang disediakan secara khusus, dimana setiap orang dapat menginap, makan serta memperoleh pelayanan dan fasilitas lainnya dengan pembayaran dan belum memenuhi 
persyaratan sebagai hotel berbintang tetapi telah memenuhi kriteria sebagai hotel melati (Kementerian Keuangan Republik Indonesia, 2012). Hotel melati dapat dibedakan menjadi 3 (tiga) yaitu :

a) Hotel melati 3

b) Hotel melati 2

c) Hotel melati 1

\subsection{Pengertian Restoran}

Restoran adalah usaha yang menyediakan, menghidangkan dan menjual makanan/minuman bagi umum di tempat usahanya bertempat di sebagian atau seluruh bangunan permanen dilengkapi dengan peralatan dan perlengkapan proses pembuatan, penyimpanan, dan penyajian (dan telah mendapatkan surat keputusan sebagai restoran dari instansi yang membinanya).

Sementara rumah makan adalah usaha yang hanya menyediakan/menjual makanan atau hidangan dan minuman bagi umum di tempat usahanya, yang pembuatannya dari bahan baku menjadi bahan jadi bias dilakukan di tempat usahanya maupun di tempat lain, tetapi tidak mempunyai fasilitas-fasilitas lain, seperti penyimpanan, pengawetan, dan sebagainya yang memenuhi kriteria sebagai restoran (Kementerian Keuangan Republik Indonesia, 2012).

\subsection{Definisi Bank}

Bank merupakan lembaga keuangan yang kegiatan usahanya menghimpun dana dari masyarakat dan menyalurkan kembali dana tersebut kemasyarakat serta memberikan jasajasa bank lainnya. Bank menjadi lembaga intermediasi keuangan, penghubung antara orang yang kelebihan modal dengan orang yang memerlukan modal. Undang-Undang No.10 Tahun 1998 Pasal 1 ayat (2) tentang Perbankan menyatakan yang dimaksud dengan bank adalah badan usaha yang menghimpun dana dari masyarakat dalam bentuk simpanan dan menyalurkannya ke masyarakat dalam bentuk kredit dan atau bentukbentuk lainnya dalam rangka meningkatkan taraf hidup rakyat banyak.

Selain itu, menurut Judisseno (2005) hakikat bank adalah suatu lembaga yang lahir karena fungsinya sebagai agent of trust dan agent of development. Definisi dari agent of trust adalah suatu lembaga perantara (intermediacy) yang dipercaya untuk melayani segala kebutuhan keuangan dari dan untuk masyarakat. Sedangkan sebagai agent of development, bank adalah suatu lembaga perantara yang dapat mendorong kemajuan pembangunan melalui fasilitas kredit dan kemudahan-kemudahan pembayaran dan penarikan dalam proses transaksi yang dilakukan oleh para pelaku ekonomi. Dari definisi di atas dapat disimpulkan bahwa bank merupakan lembaga keuangan yang kegiatannya adalah (Kasmir, 2010):

a) Menghimpun dana (uang) dari masyarakat dalam bentuk simpanan. Bank bertindak sebagai tempat menyimpan uang atau berinvestasi bagi masyarakat. Tujuan utama masyarakat menyimpan uang di bank untuk menjaga keamanan uang mereka. Sedangkan tujuan kedua untuk melakukan investasi dengan harapan memperoleh bunga dari hasil investasinya.

b) Menyalurkan dana ke masyarakat dalam bentuk pinjaman (kredit) kepada masyarakat yang mengajukan permohonan.

c) Memberikan jasa-jasa bank lainnya, seperti pengiriman uang (transfer), penagihan surat-surat berharga yang berasal dari dalam kota (clearing), penagihan surat-surat berharga yang berasal dari luar kota dan luar negeri (inkaso), letter of credit (L/C), safe deposit box, bank garansi, bank notes, travellers cheque, dan jasa lainnya. 
Bank di Indonesia dapat dikelompokkan menjadi dua jenis bank berdasarkan pembayaran bunga atau bagi hasil usaha:

1) Bank yang melakukan usaha secara konvensional.

2) Bank yang melakukan usaha secara syariah.

\subsubsection{Karakteristik Bank Syariah}

Secara umum bank adalah insititusi yang memiliki tiga fungsi utama yaitu menyimpan uang, menyalurkan uang, dan jasa pemindahan uang. Praktek menyimpan uang, menyalurkan uang untuk konsumsi dan perdagangan, serta transfer uang, sudah dilakukan secara individu saat masa Nabi Muhammad SAW., dan merupakan bagian yang tidak terlepaskan dalam kehidupan sehari-hari. Aktifitas tersebut berkembang pada era Muawiyah, tahun 661- 680 Masehi dan sesudahnya dengan nama Jihbiz, yang dikelola secara perorangan, kemudian fungsi-fungsi tersebut berkembang dan berevolusi menjadi bentuk lembaga perbankan seperti sekarang (Karim, 2005).

Bank Syari'ah merupakan bank yang beroperasi sesuai dengan ketentuan syariat Islam. Beberapa ahli ekonomi memberikan pengertian yang lebih luas mengenai Bank Syariah antara lain.

1. Antonio (2002) menyatakan Bank Syariah adalah bank yang beroperasi sesuai dengan prinsip-prinsip syari'ah Islam. Selain itu, bank syariah juga didefinisikan sebai bank yang tata cara beroperasinya mengacu pada ketentuan-ketentuan Al-Quran dan Hadist.

2. Ascarya dan Yuanita (2005) menyatakan Bank Syariah adalah bank yang melaksanakan kegiatan usaha berdasarkan prinsip Syariah, yaitu aturan perjanjian berdasarkan hukum Islam antara bank dan pihak lain untuk penyimpanan dana dan atau pembiayaan kegiatan usaha, atau kegiatan lainnya yang dinyatakan sesuai dengan Syariah.

\subsubsection{Perbedaan Bank Syariah dengan Bank Konvensional}

Bank konvensional dan bank syariah merupakan bank yang tumbuh dan berkembang dalam perekonomian masyarakat saat ini. Bank konvensional dan bank syariah memiliki persamaan, terutama dalam menjalankan perannya sebagai intermediator yaitu menghimpun dana dari masyarakat dalam bentuk tabungan kemudian menyalurkannya kembali kepada masyarakat dalam bentuk pinjaman. Persamaan lain yang dimiliki oleh perbankan adalah mekanisme transfer, teknologi komputer, syarat-syarat umum memperoleh pembiayaan. Akan tetapi, bank syariah dan bank konvensional memiliki perbedaan mendasar. Perbedaan ini menyangkut aspek legal, struktur organisasi, usaha yang dibiayai, dan lingkungan kerja. Perbedaan mendasar antara Bank Syariah dengan Bank Konvensional terletak pada dua konsep yaitu konsep sistem perbankan dan konsep imbalan. Perbedaan tersebut antara lain sebagai berikut.

Tabel 2 Perbedaan Bank Konvensional dan Bank Syariah

\begin{tabular}{|c|c|c|}
\hline & Bank Konvensional & Bank Syariah \\
\hline Fungsi dan Kegiatan Bank & Intermediasi, Jasa keuangan & $\begin{array}{l}\text { Intermediasi, Manajer Investasi, } \\
\text { Investor, Sosial, Jasa Keuangan }\end{array}$ \\
\hline Mekanisme dan Objek Usaha & $\begin{array}{l}\text { Tidak antiriba dan } \\
\text { antimaysir }\end{array}$ & Antiriba dan antimaysir \\
\hline Prinsip Dasar Operasi & $\begin{array}{l}\text { Bebas nilai (prinsip } \\
\text { materialis) } \\
\text { Uang sebagai Komoditi } \\
\text { Bunga }\end{array}$ & $\begin{array}{l}\text { Tidak bebas nilai (prinsip } \\
\text { syariah islam) } \\
\text { Uang sebagai alat tukar dan } \\
\text { bukan komoditi } \\
\text { Bagi hasil, jual beli, sewa }\end{array}$ \\
\hline Prioritas Pelayanan & Kepentingan pribadi & Kepentingan publik \\
\hline Orientasi & Bank Komersil & Bank komersil, \\
\hline
\end{tabular}




\begin{tabular}{|c|c|c|}
\hline Bentuk & $\begin{array}{l}\text { Kepastian pengembalian } \\
\text { pokok dan bunga }\end{array}$ & $\begin{array}{l}\text { Lebih hati-hati } \\
\text { partisipasi dalam risiko }\end{array}$ \\
\hline Evaluasi Nasabah & $\begin{array}{l}\text { Kepastian pengembalian } \\
\text { pokok dan bunga }\end{array}$ & $\begin{array}{l}\text { Lebih hati-hati } \\
\text { partisipasi dalam risiko }\end{array}$ \\
\hline Hubungan Nasabah & Terbatas debitur-kreditur & Erat sebagai mitra usaha \\
\hline $\begin{array}{l}\text { Sumber Likuiditas Jangka } \\
\text { Pendek }\end{array}$ & Pasar Uang, Bank Sentral & $\begin{array}{l}\text { Pasar Uang Syariah, Bank } \\
\text { Syariah }\end{array}$ \\
\hline Pinjaman yang diberikan & $\begin{array}{l}\text { Komersial dan non } \\
\text { komersial, berorientasi laba }\end{array}$ & $\begin{array}{l}\text { Komersial dan non komersial, } \\
\text { berorientasi nirlaba }\end{array}$ \\
\hline $\begin{array}{l}\text { Lembaga } \\
\text { Sengketa }\end{array}$ & Pengadilan, Arbitrase & $\begin{array}{l}\text { Pengadilan, Badan Arbitrase } \\
\text { Syariah Nasional }\end{array}$ \\
\hline Risiko Usaha & $\begin{array}{l}\text { Risiko bank tidak terkait } \\
\text { langsung dengan debitur, } \\
\text { risiko debitur }\end{array}$ & $\begin{array}{l}\text { Dihadapi bersama antara bank } \\
\text { dan nasabah dengan prinsip } \\
\text { keadilan dan kejujuran }\end{array}$ \\
\hline & $\begin{array}{ll}\text { Kemungkinan } & \text { terjadi } \\
\text { negative spread }\end{array}$ & $\begin{array}{l}\text { Tidak mungkin terjadi negative } \\
\text { spread }\end{array}$ \\
\hline Struktur Organisasi Pengawas & Dewan Komisaris & $\begin{array}{ll}\text { Dewan Komisaris, } & \text { Dewan } \\
\text { Pengawas Syariah, } & \text { Dewan } \\
\text { Syariah Nasional } & \end{array}$ \\
\hline Investas & Halal atau haram & Halal \\
\hline
\end{tabular}

Sumber: Ascarya, 2008

\subsubsection{Penyaluran Dana}

Penyaluran dana dalam bank syariah dikenal dengan nama pembiayaan. Pengertian pembiayaan menurut Undang-Undang perbankan No. 10 tahun 1998 adalah penyediaan uang atau tagihan yang dipersamakan dengan itu berdasarkan persetujuan atau kesepakatan antara bank dan pihak lain yang mewajibkan pihak yang dibiayai untuk mengembalikan uang atau tagihan tersebut setelah jangka waktu tertentu dengan imbalan atau bagi hasil.

\subsection{Pembiyaan dalam Islam}

Pembiayaan adalah salah satu jenis kegiatan usaha bank syariah. Yang dimaksud dengan pembiyaan adalah penyediaan dana atau tagihan yang dipersamakan dengan itu berupa (Wangsawidjaja 2012):

a. Transaksi bagi hasil dalam bentuk mudharabah dan musyarakah.

b. Transaksi sewa-menyewa dalam bentuk ijarah atau sewa beli dalam bentuk ijarah muntahiya bittamlik.

c. Transaksi jual beli dalam bentuk piutang murabahah, salam, dan istisna.

d. Transaksi pinjam-meminjam dalam bentuk piutang qard.

e. Transaksi sewa-menyewa jasa dalam bentyk ijarah untuk transaksi multijasa.

Pembiayaan merupakan salah satu instrumen yang dimiliki perbankan syariah dalam melaksanakan fungsinya sebagai lembaga intermediasi. Selain perbankan lembaga keuangan lainnya adalah Baitul Mal Wa Tamwil (BMT) sebagai lembaga keuangan non bank yang memberikan pembiayaan kepada pengusaha yang tidak bankable.

\subsubsection{Jenis Pembiayaan Syariah}

Penyaluran dana perbankan pada bank konvensional disebut dengan istilah kredit atau pinjaman, sedangkan dalam bank syariah penyaluran dana disebut dengan istilah pembiayaan (Kasmir 2002). Pembiayaan merupakan salah satu tugas pokok bank, yaitu pemberian fasilitas penyediaan dana untuk memenuhi kebutuhan pihak pihak yang 
merupakan defisit unit. Menurut Antonio (2002), pembiayaan dapat dibagi menjadi dua hal berdasarkan sifat penggunaannya, yaitu:

1) Pembiayaan Produktif, yaitu pembiayaan yang ditujukan untuk memenuhi kebutuhan produksi dalam arti luas, yaitu untuk peningkatan usaha baik usaha produksi, perdagangan maupun investasi. Menurut keperluannya, pembiayaan produktif dapat dibagi menjadi dua hal berikut:

a. Pembiayaan modal kerja, yaitu pembiayaan untuk memenuhi kebutuhan peningkatan produksi, baik secara kuantitatif yaitu jumlah hasil produksi, maupun secara kualitatif yaitu peningkatan kualitas atau mutu hasil produksi serta untuk keperluan perdagangan atau peningkatan utility of place dari suatu barang.

b. Pembiayaan investasi, yaitu untuk memenuhi kebutuhan barang barang modal (capital goods) serta fasilitas fasilitas yang erat kaitannya dengan itu.

2) Pembiayaan konsumtif, yaitu pembiayaan yang digunakan untuk memenuhi kebutuhan konsumsi yang akan habis digunakan untuk memenuhi kebutuhan.

\subsection{Definisi Variabel}

Kusumawati (2013) membagi faktor-faktor yang memengaruhi pembiayaan pada perbankan syariah menjadi 4 kategori yaitu kategori kinerja perbankan syariah dengan variabel Dana Pihak Ketiga (DPK), Financing to Deposit Ratio (FDR) dan Non Performing Financing (NPF), kategori kondisi makro dengan variabel Industrial Production Index (IPI) dan tingkat Inflasi (INF), kategori instrumen moneter dengan variabel Bonus Sertifikat Bank Indonesia Syariah (BSBIS), Suku Bunga Sertifikat Bank Indonesia (SBI) dan volume penempatan pada Pasar Uang Antarbank Syariah (PUAS), dan kategori return pembiayaan dengan variabel Equivalent rate (ERP) dan Suku Bunga Kredit (SBK). Variabel yang dipakai pada penelitian ini adalah DPK, NPF, IPI, INF, SBIS, PUAS, ERP, dan SBK.

\subsection{Kategori Kinerja Perbankan}

Pengertian kinerja adalah ukuran seberapa efisien dan efektif seorang manajer atau sebuah organisasi mencapai tujuan yang memadai. Kinerja adalah melakukan pekerjaan dan hasil yang dicapai dari pekerjaan tersebut.

\section{Dana Pihak Ketiga (DPK)}

Dana pihak ketiga (simpanan) yang dijelaskan dalam Undang-Undang Perbankan RI No. 10 tahun 1998 tentang perbankan adalah dana yang dipercayakan oleh masyarakat kepada bank berdasarkan perjanjian penyimpanan dana dalam bentuk giro, deposito, sertifikat deposito, tabungan, dan atau bentuk lainnya yang dipersamakan dengan itu.

Menurut Kasmir (2002) dana pihak ketiga adalah dana yang berasal dari masyarakat luas yang merupakan sumber dana terpenting bagi kegiatan operasional suatu bank dan merupakan ukuran keberhasilan bank jika mampu membiayai operasionalnya dari sumber dana ini. Sumber dana ini merupakan sumber dana terpenting bagi kegiatan operasional bank dan merupakan ukuran keberhasilan bank jika mampu membiayai operasionalnya dari sumber dana ini. Menurut Undang-Undang Perbankan No. 10 tahun 1998 sumber dana yang dimaksud adalah sebagai berikut :

a) Giro adalah simpanan yang penarikannya dapat dilakukan setiap saat dengan menggunakan cek, bilyet giro, sarana perintah pembayaran lainnya atau dengan cara pemindahbukuan. 
b) Deposito adalah simpanan yang penarikannya hanya dilakukan pada waktu tertentu berdasarkan perjanjian nasabah penyimpan dengan bank.

c) Tabungan adalah simpanan yang penarikannya hanya dapat dilakukan menurut syarat-syarat tertentu yang disepakati, tetapi tidak dapat ditarik dengan cek, bilyet giro, dan atau alat lainnya yang dipersamakan dengan itu.

\section{Non Performing Financing (NPF)}

Istilah Non Performing Financing (NPF) dipakai pada perbankan syariah sedangkan pada perbankan konvensional dikenal dengan istilah Non Performing Loan (NPL). Bank Indonesia menyatakan NPF adalah rasio yang menunjukkan banyaknya nilai kewajiban atas nilai pembiayaan yang belum dibayar oleh nasabah.

\section{Kategori Kondisi Makro}

Makroekonomi merupakan suatu studi tentang bagaimana sistem perekonomian berjalan secara garis besar, tanpa terlalu banyak menaaruh perhatian pada hal-hal yang bersifat rinci dan rancu (Lipsey, 1995)

\section{Industrial Production Index (IPI)}

Badan Pusat Statistik menyatakan bahwa IPI adalah angka indeks yang menggambarkan perkembangan produksi sektor industri secara lebih dini karena sifatnya dirancang secara periodik bulanan.

\section{Tingkat Inflasi (INF)}

Badan Pusat Statistik mendefinisikan inflasi sebagai salah satu indikator untuk melihat stabilitas ekonomi suatu wilayah atau daerah yang menunjukkan perkembangan harga barang dan jasa secara umum yang dihitung dari indeks harga konsumen. Dengan demikian angka inflasi sangat mempengaruhi daya beli masyarakat yang berpenghasilan tetap, dan di sisi lain juga mempengaruhi besarnya produksi barang.

\section{Kategori Instrumen Moneter}

Ascarya (2002) menjelaskan kebijakan moneter sebagai salah satu kebijakan ekonomi yang berperan penting dalam perekonomian. Peranan tersebut tercermin pada kemampuannya dalam memengaruhi stabilitas harga, pertumbuhan ekonomi, perluasan kesempatan kerja, dan keseimbangan neraca pembayaran. Kebijakan moneter dapat menggunakan instrumen baik langsung maupun tidak langsung. Instrumen langsung adalah instrumen pengendalian moneter yang dapat secara langsung memengaruhi sasaran operasional yang diinginkan bank sentral. Adapun instrumen tidak langsung adalah instrumen pengendalian moneter yang secaara tidak langsung dapat memengaruhi sasaran operasional yang diinginkan oleh bank sentral.

\section{Bonus Sertfikat Bank Indonesia Syariah (SBIS)}

Berdasarkan PBI nomor 10 no.2 (2000) menyatakan bahwa SBIS adalah surat berharga berdasarkan prinsip syariah berjangka waktu pendek dalam mata uang rupiah yang diterbitkan oleh Bank Indonesia. 


\section{Penempatan Dana pada Pasar Uang Antarbank Syariah (PUAS)}

Fatwa Dewan Syariah Nasional Majelis Ulama Indonesia (DSN-MUI) no 37 menyatakan PUAS adalah kegiatan transaksi keuangan jangka pendek antarpeserta pasar berdasarkan prinsip-prinsip syariah. Bank Indonesia (PBI) no.2 (2000) menyatakan PUAS adalah kegiatan investasi jangka pendek dalam rupiah antarpeserta pasar berdasarkan prinsip Mudharabah.

\section{Kategori Return Pembiayaan}

Return adalah hasil yang diperoleh dari investasi. Jogiyanto (2003) menjelaskan bahwa return dapat terbagi menjadi dua, yaitu:

1. Return realisasi (realized return) merupakan return yang telah terjadi. Return realisasi dihitung berdasarkan data historis. Return realisasi penting karena digunakan sebagai salah satu pengukur kinerja dari perusahaan. Return historis ini juga berguna sebagai dasar penentuan return ekspektasi (expected return) dan risiko di masa mendatang.

2. Return ekspektasi (expected return) adalah return yang diharapkan akan diperoleh oleh investor di masa mendatang. Berbeda dengan return realisasi yang sifatnya sudah terjadi, return ekspektasi sifatnya belum terjadi.

\section{Equivalent Rate (ERP)}

Hanafi (2003) menjelaskan jika Equivalent Rate atau Suku bunga padanan adalah suku bunga yang besarnya dihitung setiap hari (bunga harian), setiap minggu (bunga mingguan), setiap bulan (bunga bulanan) atau setiap tahun (bunga tahunan) untuk sejumlah pinjaman (kredit) atau investasi selama jangka waktu tertentu yang apabila dihitung anuitas (bunga berbunga) akan memberikan penghasilan dengan jumlah yang sama.

\section{Suku Bunga Dasar Kredit (SBK)}

Surat Edaran Bank Indonesia (SE-BI) no. 15 tahun 2013 menyatakan bahwa Suku Bunga Dasar Kredit (SBDK) merupakan suku bunga terendah yang mencerminkan kewajaran biaya yang dikeluarkan oleh Bank termasuk ekspektasi keuntungan yang akan diperoleh. Selanjutnya SBDK digunakan sebagai dasar bagi Bank dalam menetapkan suku bunga kredit yang akan dikenakan kepada nasabah. SBDK dihitung secara per tahun dalam bentuk persentase (\%) yang penghitungannya dilakukan berdasarkan 3 (tiga) komponen yaitu:

1) Harga Pokok Dana untuk Kredit (HPDK) yang timbul dari kegiatan penghimpunan dana;

2) Biaya overhead yang dikeluarkan bank berupa beban operasional bukan bunga yang dikeluarkan untuk kegiatan penghimpunan dana dan penyaluran kredit termasuk biaya pajak yang harus dibayar; dan

3) Marjin keuntungan (profit margin) yang ditetapkan Bank dalam kegiatan penyaluran kredit.

Penghitungan SBDK berlaku untuk jenis kredit:

a) Kredit korporasi;

b) Kredit ritel;

c) Kredit mikro; dan

d) Kredit konsumsi (KPR dan Non KPR). Kredit konsumsi non KPR tidak termasuk penyaluran dana melalui kartu kredit dan kredit tanpa agunan (KTA).

Dalam penelitian ini Suku Bunga Dasar Kredit ditulis SBK. 


\subsection{Tinjauan Penelitian Terdahulu}

Penelitian tentang pembiayaan oleh perbankan syariah telah banyak dilakukan, namun penelitian yang memfokuskan pada sektor perdagangan, hotel, dan restoran (PHR) masih belum dilakukan. Maka penelitian ini akan mengkaji rasio pembiayaan perbankan syariah pada sektor PHR dikaitkan dengan berbagai faktor.

Penelitian tentang keterkaitan penyaluran dana perbankan dengan kondisi makroekonomi dilakukan oleh Talavera et al. (2006). Penelitian tersebut mengkaji keterkaitan antara perilaku penyaluran kredit bank dan ketidakpastian makroekonomi yang terjadi di Ukraina periode tahun 2003 kuartal pertama sampai tahun 2005 kuartal ketiga. Model yang digunakan adalah ekulibrium parsial dinamik dengan variabel yang digunakan adalah: rasio kredit terhadap modal, rasio dana pihak ketiga terhadap modal, dan natural log modal sendiri, sedangkan indikator ketidakpastian makroekonomi yang digunakan adalah M1, M2, Consumer Price Index (CPI), serta Produser Price Index (PPI). Hasil penelitiannya menunjukkan bahwa perbankan di Ukraina menurunkan penawaran kreditnya jika ketidakpastian peubah makroekonomi meningkat, demikian pula sebaliknya, jika ketidakpastian makroekonomi menurun maka penawaran kredit perbankan meningkat.

Penelitian yang dilakukan Nugroho (2009) terhadap pembiayaan perbankan syariah dengan menggunakan metode VAR-VECM mendapati bahwa dalam jangka panjang pembiayaan bermasalah dan kredit bank umum signifikan mempengaruhi pembiayaan perbankan syariah. Guncangan dari pembiayaan bermasalah, SWBI, kredit bank umum, indeks produksi industri, dan Jakarta Islamic Index direspon permanen negatif oleh pembiayaan, sedangkan laba per-aset, DPK, dan pembiayaan sendiri direspon permanen positif oleh pembiayaan. Berdasarkan kontribusi dinamis masing-masing peubah, peubah yang paling besar menjelaskan variabilitas pembiayaan adalah pembiayaan bermasalah, kemudian pembiayaan itu sendiri dan kredit bank umum .

Penelitian yang dilakukan Ghafur (2007) mengenai pengaruh resiko keuangan bank terhadap keputusan pembiayaan bank syariah. Penelitian ini menggunakan Bank Mualamalat Indonesia sebagai objek penelitian dengan model dinamik Autoregressive Distributed Lag (ADL). Hasil penelitian menunjukkan bahwa variabel Assets Utilization Ratio (AUR), DPK, dan FDR memiliki pengaruh positif dalam memengaruhi pembiayaan secara langsung pada periode saat ini. Hal ini menunjukkan bahwa ketiga variabel tersebut tidak memerlukan penyesuaian waktu dalam memengaruhi pembiayaan secara positif. Sedangkan variabel Loan to Asset Ratio (LAR), Rate of Return on Loan Ratio (RLR) dan CAR pada periode lalu memiliki pengaruh positif terhadap pembiayaan yang menunjukkan bahwa ketiga variabel tersebut membutuhkan waktu (kelambanan/lag) dalam memengaruhi pembiayaan perbankan syariah.

Penelitian yang dilakukan oleh Aprianti (2011) menganalisis faktor-faktor yang memengaruhi pembiayaan sektor pertanian perbankan syariah menggunakan variabelvariabel dari sisi konvensional maupun syariah. Hasil penelitiannya menunjukan untuk variabel equivalent rate DPK, equivalent rate pembiayaan pertanian, Bonus SBIS, dan suku bunga SBI signifikan berpengaruh secara positif terhadap pembiayaan pertanian. Sedangkan untuk variabel suku bunga kredit dan jumlah DPK signifikan berpengaruh negatif terhadap pembiayaan pertanian. Secara teori, seharusnya DPK memiliki pengaruh positif terhadap kenaikan pembiayaan. Berdasarkan dari hasil penelitiannya menunjukkan bahwa perbankan syariah belum memfokuskan pembiayaannya pada sektor pertanian karena belum adanya skim pembiayaan yang tepat untuk sektor pertanian. 
Penelitian Kusumawati (2013) menganalisis faktor-faktor yang memengaruhi pembiayaan sektor konstruksi perbankan syariah menggunakan variabel-variabel dari sisi konvensional maupun syariah. Hasil penelitiannya menunjukkan ketika variabel DPK, SBK, NPF, BSBIS, dan PUAS mengalami keguncangan satu standar deviasi maka akan direspon secara negatif oleh rasio pembiayaan sektor konstruksi perbankan syariah. Sedangkan bila terjadi guncangan pada FDR, SBI, IPI, INF, dan ERP sebesar satu standar deviasi maka akan direspon secara positif oleh rasio pembiayaan sektor konstruksi. Variabel yang membentuk keragaman pada pembiayaan sektor konstruksi dengan kontribusi yang paling besar dijelaskan oleh variabel Dana Pihak Ketiga (DPK), inflasi, dan penempatan dana pada pasar uang dengan prinsip syariah (PUAS).

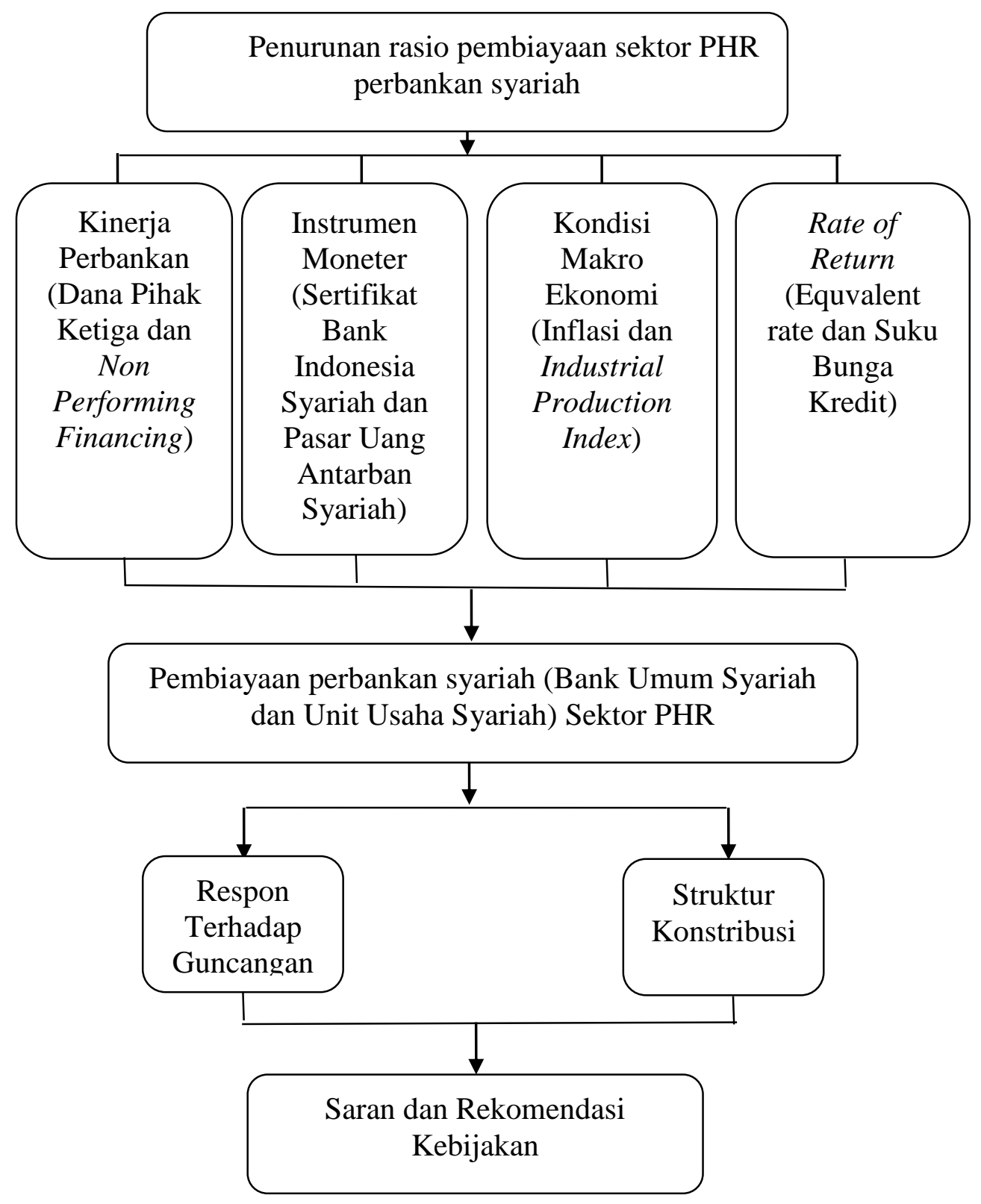

\section{Gambar 5 Kerangka pemikiran}


Berdasarkan kerangka pemikiran konseptual dan tinjauan pustaka maka hipotesis dari penelitian ini antara lain :

1. Variabel Dana Pihak Ketiga (DPK), Industrial Production Index (IPI), bonus SBIS (SBIS), dan equivalent rate pembiayaan (ERP) memiliki hubungan yang positif terhadap pembiayaan sektor PHR pada perbankan syariah.

2. Variabel suku bunga kredit (SBK), pembiayaan bermasalah (NPF), tingkat inflasi, dan penempatan pada PUAS memiliki hubungan yang negatif terhadap sektor PHR pada perbankan syariah.

\section{Metode Penelitian}

\subsection{Jenis dan Sumber Data}

Data yang digunakan yaitu data sekunder dengan frekuensi bulanan dari Januari 2008 sampai dengan Desember 2012 yang bersangkutan dengan pembiayaan yang diberikan Bank Umum Syariah (BUS) dan Unit Usaha Syariah (UUS). Data bersumber dari publikasi Bank Indonesia antara lain Statistik Perbankan Syariah Bank Indonesia (SPS BI), Statistik Perbankan Indonesia (SPI), Direktorat Perbankan Syariah Indonesia (DPbSBI) dan Statistik Ekonomi dan Keuangan Indonesia (SEKI), serta data dari Badan Pusat Statistika (BPS). Penelitian ini juga menggunakan data pelengkap lainnya dari literaturliteratur yang berkaitan, jurnal, buku, dan dari media internet.

Tabel 3 Jenis dan Sumber data

\begin{tabular}{|c|c|c|c|c|}
\hline No & Peubah & Simbol & Satuan & Sumber Data \\
\hline 1 & Pembiayaan Sektor PHR & Rasio_PPHR & persen & BI \\
\hline 2 & Jumlah Dana Pihak Ketiga & DPK & Miliar Rp & BI \\
\hline 3 & $\begin{array}{l}\text { Industrial } \quad \text { Production } \\
\text { Index/Jakarta Islamic index }\end{array}$ & IPI & Index & BPS \\
\hline 4 & Suku Bunga Kredit & SBK & Persen & BI \\
\hline 5 & Tingkat Inflasi & INF & Persen & $\mathrm{BI}$ \\
\hline 6 & Pembiayaan bermasalah & NPF & Persen & $\mathrm{BI}$ \\
\hline 7 & Bonus SBIS & SBIS & Persen & $\mathrm{BI}$ \\
\hline 8 & Penempatan dana pada PUAS & PUAS & Persen & BI \\
\hline 9 & $\begin{array}{l}\text { Equivalent rate Pembiayaan } \\
\text { periode ke-t }\end{array}$ & ERP & Miliar Rp & $\mathrm{BI}$ \\
\hline
\end{tabular}

Sumber : Data dengan Sumber (diolah)

\subsection{Metode Analisis Data}

Penelitian ini menggunakan metode analisis yang bersifat deskriptif dan kuantitatif. Alat analisis yang digunakan dalam penelitian ini adalah metode Vector Autoregression (VAR) apabila data-data yang digunakan stasioner dan tidak terkointegrasi, kemudian dilanjutkan dengan metode Vector Correction Model (VECM) apabila data-data yang digunakan stasioner dan terdapat kointegrasi. Sebelum sampai pada analisis VAR dan VECM perlu dilakukan beberapapengujian praestimasi yaitu, uji stasioneritas data atau uji akar unit (unit root test), penentuan panjang lag optimum, dan uji stabilitas VAR. Selanjutnya, akan dilakukan uji kausalitas Granger, uji kointegrasi, VECM, teknik Impuls Response Function (IRF), dan Forecast Error Decomposition of Variance (FEDV). Perangkat lunak yang digunakan untuk proses pengolahan adalah Microsoft Excel 2007 dan Eviews 6. 


\subsubsection{Implementasi Model VECM}

Model persamaan VECM dalam bentuk notasi matriks yang digunakan dalam penelitian ini mengacu pada penelitian yang dilakukan Kusumawati (2013) yang berjudul Analisis Pembiayaan Sektor Konstruksi pada Perbankan Syariah di Indonesia. Kusumawati (2013) membagi faktor-faktor yang memengaruhi pembiayaan pada perbankan syariah dibagi menjadi 4 kategori yaitu kategori kinerja perbankan syariah dengan variabel Dana Pihak Ketiga (DPK) dan Non Performing Financing (NPF), kategori kondisi makro dengan variabel Industrial Production Index (IPI) dan tingkat Inflasi (INF), kategori instrumen moneter dengan variabel Bonus Sertifikat Berharga Indonesia Syariah (SBIS) dan volume penempatan pada Pasar Uang Antarbank Syariah (PUAS), dan kategori return pembiayaan dengan variabel Equivalent rate (ERP) dan Suku Bunga Kredit (SBK). Sehingga model yang dipakai di penelitian ini adalah sebagai berikut:

$$
\begin{aligned}
& {\left[\begin{array}{c}
\Delta \mathrm{RASIO} \\
\Delta \ln _{\mathrm{DPHT}} \\
\Delta \mathrm{ERPt} \\
\Delta \mathrm{INFt} \\
\Delta \ln _{\mathrm{IPIt}} \\
\Delta \mathrm{NPFt} \\
\Delta \ln _{\mathrm{PUASt}} \\
\Delta \mathrm{SBISt} \\
\Delta \mathrm{SBKt}
\end{array}\right]} \\
& =\left[\begin{array}{l}
\alpha 10 \\
\alpha 20 \\
\alpha 30 \\
\alpha 40 \\
\alpha 50 \\
\alpha 60 \\
\alpha 70 \\
\alpha 80 \\
\alpha 90
\end{array}\right] \\
& +\left[\begin{array}{lllllllll}
\alpha 11 & \alpha 12 & \alpha 13 & \alpha 14 & \alpha 15 & \alpha 16 & \alpha 17 & \alpha 18 & \alpha 19 \\
\alpha 21 & \alpha 22 & \alpha 23 & \alpha 24 & \alpha 25 & \alpha 26 & \alpha 27 & \alpha 28 & \alpha 29 \\
\alpha 31 & \alpha 32 & \alpha 33 & \alpha 34 & \alpha 35 & \alpha 36 & \alpha 37 & \alpha 38 & \alpha 39 \\
\alpha 41 & \alpha 42 & \alpha 43 & \alpha 44 & \alpha 45 & \alpha 46 & \alpha 47 & \alpha 48 & \alpha 49 \\
\alpha 51 & \alpha 52 & \alpha 53 & \alpha 54 & \alpha 55 & \alpha 56 & \alpha 57 & \alpha 58 & \alpha 59 \\
\alpha 61 & \alpha 62 & \alpha 63 & \alpha 64 & \alpha 65 & \alpha 66 & \alpha 67 & \alpha 68 & \alpha 69 \\
\alpha 71 & \alpha 72 & \alpha 73 & \alpha 74 & \alpha 75 & \alpha 76 & \alpha 77 & \alpha 78 & \alpha 79 \\
\alpha 81 & \alpha 82 & \alpha 83 & \alpha 84 & \alpha 85 & \alpha 86 & \alpha 87 & \alpha 88 & \alpha 89 \\
\alpha 91 & \alpha 92 & \alpha 93 & \alpha 94 & \alpha 95 & \alpha 86 & \alpha 97 & \alpha 98 & \alpha 99
\end{array}\right]\left[\begin{array}{c}
\Delta \text { RASIO }_{P P H R t-1} \\
\Delta \ln _{\text {DPKt-1 }} \\
\Delta \mathrm{ERPt}-1 \\
\Delta \mathrm{INFt}-1 \\
\Delta \ln _{\text {IPIt }-1} \\
\Delta \mathrm{NPFt}-1 \\
\Delta \ln _{\text {PUASt }}-1 \\
\Delta \mathrm{BSBISt}-1 \\
\Delta \mathrm{SBKt}-1
\end{array}\right]\left[\begin{array}{c}
\varepsilon 1 \mathrm{t} \\
\varepsilon 2 \mathrm{t} \\
\varepsilon 3 \mathrm{t} \\
\varepsilon 4 \mathrm{t} \\
\varepsilon 5 \mathrm{t} \\
\varepsilon 6 \mathrm{t} \\
\varepsilon 7 \mathrm{t} \\
\varepsilon 8 \mathrm{t} \\
\varepsilon 9 \mathrm{t}
\end{array}\right]
\end{aligned}
$$




\section{Hasil dan Pembahasan}

\subsection{Uji Stasioner}

Pengujian stasioner menggunakan uji Augmented Dickey Fuller (ADF). Pengujian dilakukan pada tahap level sampai dengan first difference dengan menggunakan asumi Schwarz Information Criterion pada automatic lag length selection dengan maximum lag sebesar 9.

Tabel 4 Tabel Uji Stasioneritas

\begin{tabular}{|c|c|c|c|c|c|c|}
\hline \multirow[t]{5}{*}{ Variabel } & \multicolumn{3}{|c|}{ LEVEL } & \multicolumn{3}{|c|}{ FIRST DIFFERENCE } \\
\hline & \multirow{4}{*}{$\begin{array}{c}\text { Nilai } \\
\text { Statistik } \\
\text { ADF }\end{array}$} & \multirow{4}{*}{$\begin{array}{c}\text { Nilai } \\
\text { Kritis Mac } \\
\text { Kinnon }\end{array}$} & \multirow[t]{4}{*}{ Keterangan } & Nilai & \multirow{4}{*}{$\begin{array}{c}\text { Nilai } \\
\text { Kritis } \\
\text { Mac } \\
\text { Kinnon }\end{array}$} & \multirow{4}{*}{$\begin{array}{c}\text { Keterang } \\
\text { an }\end{array}$} \\
\hline & & & & Statistik & & \\
\hline & & & & ADF & & \\
\hline & & & & & & \\
\hline \multirow[t]{2}{*}{ PHR } & - & -3.475305 & Stasioner & -12.8267 & -3.475305 & Stasioner \\
\hline & 3.59964 & & & & & \\
\hline \multirow[t]{2}{*}{ DPK } & - & -3.474436 & Tidak & -8.617318 & -3.475305 & Stasioner \\
\hline & 2.16358 & & Stasioner & & & \\
\hline \multirow[t]{2}{*}{ ERP } & - & -2.903566 & Tidak & -10.86878 & -2.903566 & Stasioner \\
\hline & 1.55804 & & stasioner & & & \\
\hline \multirow[t]{2}{*}{ INF } & - & -2.903566 & Stasioner & -7.472198 & -2.905519 & Stasioner \\
\hline & 5.14750 & & & & & \\
\hline \multirow[t]{2}{*}{ IPI } & - & -3.474363 & Stasioner & -8.596196 & -3.476275 & Stasioner \\
\hline & 5.92416 & & & & & \\
\hline \multirow[t]{2}{*}{ NPF } & - & -3.474363 & Tidak & -2.722460 & -2.591006 & Stasioner \\
\hline & 3.39882 & & stasioner & & & \\
\hline \multirow[t]{2}{*}{ PUAS } & - & -2.903566 & Tidak & -6.086218 & -2.906210 & Stasioner \\
\hline & 2.31737 & & stasioner & & & \\
\hline \multirow[t]{2}{*}{ SBIS } & - & -2.903566 & Tidak & -3.648369 & -2.904198 & Stasioner \\
\hline & 1.89320 & & stasioner & & & \\
\hline \multirow[t]{2}{*}{ SBK } & - & -2.903566 & Tidak & -9.521833 & -2.903566 & Stasioner \\
\hline & 1.16655 & & stasioner & & & \\
\hline
\end{tabular}

Data dikatakan stasioner adalah ketika hasil t-hitung lebih kecil daripada t-kritis MacKinnon. Hasil yang dicetak tebal pada tabel menunjukkan data yang stasioner baik pada level maupun $1^{\text {st }}$ difference. Hasil menunjukkan variabel yang stasioner di level hanya rasio pembiayaan PHR (PHR), tingkat inflasi (INF) dan Industrial Production Index (IPI). Sedangkan pada $1^{\text {st }}$ difference semua variabel stasioner. Oleh karena itu, akan dilakukan pengujian kointegrasi, jika terdapat kointegrasi maka akan digunakan metode Vector Error Correction Model (VECM), namun jika tidak terdapat kointegrasi maka akan digunakan VAR $1^{\text {st }}$ difference.

\subsection{Uji Selang Optimal}

Firdaus (2011) menyatakan bahwa uji selang optimal digunakan untuk mengetahui seberapa lama pengaruh suatu variabel terhadap variabel lainnya. Selain itu, pengujian selang optimal digunakan untuk menghindari adanya autokorelasi di dalam model.

Tabel 5 Tabel Uji Lag Optimal

\begin{tabular}{cccccccc}
\hline Lag & 0 & 1 & 2 & 3 & 4 & 5 & 6 \\
SC & -44.98609 & - & - & - & - & - & - \\
& & $\mathbf{5 4 . 5 5 9 1 7} *$ & 51.66799 & 48.41119 & 46.03599 & 45.66166 & 51.63610 \\
\hline
\end{tabular}

Keterangan : *lag optimal 
Kriteria selang optimal yang digunakan adalah Schwarz Information Criterion. Hasil menunjukkan bahwa selang optimum terdapat pada selang 1, yaitu ditunjukkan oleh tanda bintang yang terdapat di dalam hasil. Hal ini mengindikasi bahwa kejadian saat ini dipengaruhi oleh kejadian 1 periode sebelumnya.

\section{Uji Stabilitas VAR}

Firdaus (2011) menyatakan bahwa uji stabilitas VAR dilakukan dengan menghitung akarakar dari fungsi polinomial atau dikenal dengan roots of characteristic polinomial. Jika nilai dari semua akar fungsi polinomial tersebut memiliki nilai absolut $<1$ atau berada di dalam unit circle maka model VAR tersebut dianggap stabil sehingga Impulse Response Function (IRF) dan Forecast Error Variance of Decomposition (FEVD) yang dihasilkan dianggap valid. Tabel stabilitas VAR yang terdapat di dalam lampiran menunjukkan nilai modulus yang berkisar antara 0.069797-0.995901. Hal ini menunjukkan bahwa model VAR yang digunakan dianggap stabil, sehingga IRF dan FEVD dianggap valid.

\section{Uji Kointegrasi}

Firdaus (2011) mengemukakan bahwa uji kointegrasi bertujuan untuk menentukan apakah variabel-variabel yang tidak stasioner terkointegrasi atau tidak. Penelitian ini menggunakan Johansen Cointegration Test dengan membandingkan antara trace statistic dan critical value. Apabila trace statistic lebih besar daripada critical value, persamaan tersebut terkointegrasi. Kointegrasi dapat diartikan sebagai hubungan jangka panjang antarvariabel.

\begin{tabular}{|c|c|c|c|c|c|c|c|c|c|c|}
\hline & \multicolumn{10}{|c|}{ ntegrasi } \\
\hline & $\mathbf{H}_{0}$ & $R=0$ & $R \leq 1$ & $R \leq 2$ & $\mathbf{R} \leq \mathbf{3}$ & $\mathrm{R} \leq 4$ & $R \leq 5$ & $R \leq 6$ & $\mathbf{R} \leq 7$ & $\mathrm{R} \leq \mathbf{8}$ \\
\hline & $\mathbf{H}_{1}$ & $R \geq 1$ & $R \geq 2$ & $\mathbf{R} \geq \mathbf{3}$ & $R \geq 4$ & $R \geq 5$ & $R \geq \mathbf{6}$ & $R \geq 7$ & $R \geq 8$ & $R \geq 9$ \\
\hline $\begin{array}{l}\text { Trace } \\
\text { Statistic }\end{array}$ & & 249.9 & 187.4 & 150.5 & 117.7 & 88.8 & $\begin{array}{l}63.8 \\
\end{array}$ & 42.9 & 25.8 & 12.5 \\
\hline $\begin{array}{l}\text { Critical } \\
\text { Value }\end{array}$ & & 228.2 & 196.8 & 117.7 & 104.5 & 73.0 & 44.5 & 28.7 & 14.5 & 4.9 \\
\hline
\end{tabular}

Berdasarkan hasil uji Johanssen's Trace Statisctic pada Tabel uji kointergrasi, model model yang digunakan pada penelitian ini memiliki dua persamaan kointegrasi. Persamaan kointegrasi ini menunjukkan bahwa diantara variabel - variabel yang diuji memiliki hubungan kombinasi liniear yang bersifat stasioner (kointegrasi), sehingga model VECM dapat dilakukan dalam penelitian ini. 


\section{Hasil Estimasi VECM}

Tabel 7 Tabel Hasil Estimasi VECM

\begin{tabular}{|l|c|c|c|}
\hline \multirow{2}{*}{ Peubah } & \multirow{2}{*}{ IRF } & \multicolumn{2}{|c|}{ VECM } \\
\cline { 3 - 4 } & & Jangka Pendek & Jangka Panjang \\
\hline PHR & + & $x$ & $\checkmark$ \\
\hline DPK & - & $x$ & $\checkmark$ \\
\hline ERP & + & $x$ & $\checkmark$ \\
\hline INF & - & $x$ & $x$ \\
\hline IPI & + & $x$ & $\checkmark$ \\
\hline NPF & - & $x$ & $x$ \\
\hline PUAS & - & $x$ & $\checkmark$ \\
\hline SBIS & - & $x$ & $\checkmark$ \\
\hline SBK & + & & \\
\hline
\end{tabular}

Keterangan :

+ : guncangan pada peubah direspon positif oleh rasio pembiayaan PHR

- : guncangan pada peubah direspon negatif oleh rasio pembiayaan PHR

$\checkmark$ : ada hubungan signifikan

$x$ : tidak ada hubungan signifikan

Hasil estimasi VECM menunjukkan pengaruh jangka panjang dan pengaruh jangka pendek. Angka yang dicetak tebal menunjukkan variabel-variabel yang signifikan. Pengaruh jangka pendek menunjukkan bahwa variabel yang signifikan hanyalah rasio pembiayaan PHR. Selain itu, kointegrasi kesalahan bernilai positif dan signifikan. Variabel-variabel lain yang tidak signifikan mengindikasikan bahwa suatu variabel bereaksi terhadap variabel lainnya membutuhkan waktu yang pada umumnya terjadi dalam jangka panjang.

Pengaruh jangka panjang menunjukkan variabel yang tidak signifikan adalah PUAS dan IPI. Dana pihak ketiga (DPK), Inflasi (INF), Non Performing Finance (NPF), dan Bonus Sertifikat Berharga Indonesia Syariah (SBIS) berpengaruh signifikan dan memiliki hubungan yang negatif yang artinya adanya kenaikan nilai pada variabel ini akan menurunkan nilai rasio pembiayaan PHR. Equivalent rate (ERP), Industrial Production Index (IPI), penempatan pada pasar uang antarbank syariah (PUAS) dan Suku Bunga Kredit (SBK) berpengaruh positif dan signifikan yang berarti naiknya nilai variabel ini akan menaikkan nilai rasio pembiayaan PHR.

\section{Impulse Response Function}

Impulse Response Function (IRF) digunakan untuk mengukur sejauh mana suatu variabel terpengaruh dari shock baik yang diakibatkan oleh variabel itu sendiri maupun variabel lainnya. Penelitian ini menganalisis respon pembiayaan PHR terhadap guncangan masing-masing faktor menggunakan standar Cholesky Decomposition pada Impuls Response Function (IRF) dengan jangka waktu 60 bulan ke depan. Analisis ini mengukur respon perubahan masing-masing variabel terhadap shock yang terjadi pada salah satu variabel dengan menggunakan satu standar deviasi. Pada analisis IRF ini akan dijelaskan perbandingan respon rasio pembiayaan sektor PHR jika terdapat guncangan pada variabel Inflasi, dana pihak ketiga (DPK), Industrial Production Index (IPI), suku bunga kredit 
(SBK), pembiayaan bermasalah (NPF), bonus SBIS (SBIS), volume PUAS dan equivalent rate pembiayaan (ERP)

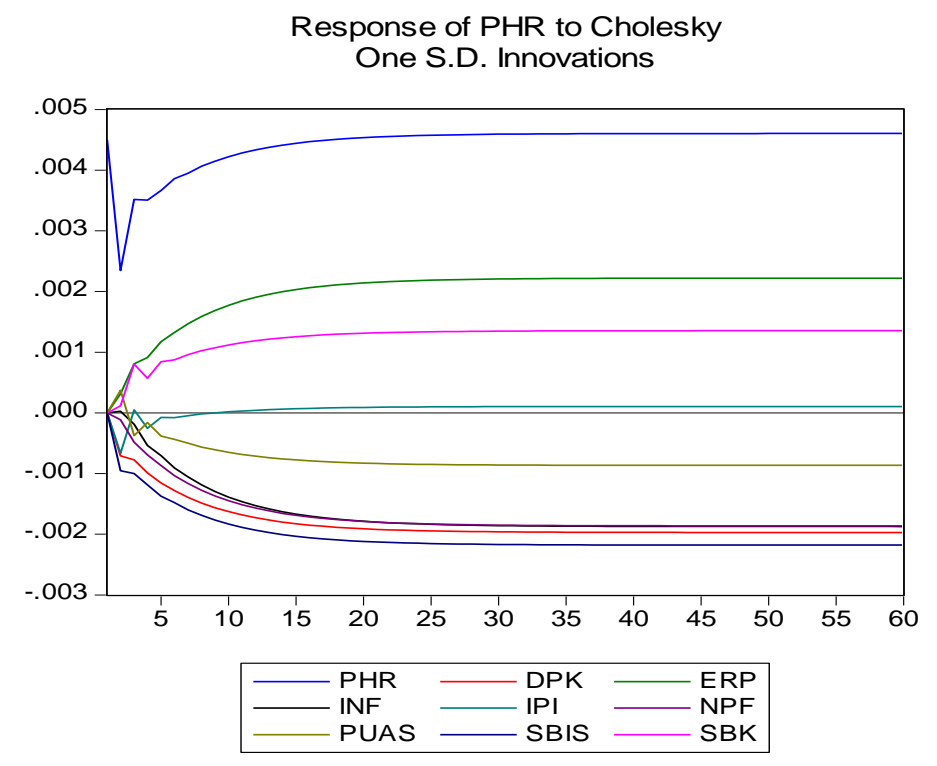

Gambar 6 Impulse Response Function

Respon rasio pembiayaan sektor PHR perbankan syariah jika terjadi guncangan:

\subsection{Guncangan pada Kategori Kinerja Perbankan Syariah}

\section{Guncangan pada Dana Pihak Ketiga (DPK)}

Respon rasio pembiayaan PHR terhadap guncangan yang terjadi pada dana pihak ketiga (DPK) belum ditunjukkan di periode pertama. Rasio pembiayaan PHR mulai merespon DPK pada periode kedua . Terjadi penurunan pada periode kedua sebesar $0.07 \%$ yang terus mengalami penurunan sampai periode ke-20 dan seterusnya cenderung stabil pada kisaran $0.19 \%$. Hal ini menunjukkan jika terjadi guncangan pada DPK seperti kenaikan pada nilai DPK maka akan berdampak pada penurunan rasio pembiayaan sektor PHR. Hal ini dikarenakan kenaikan DPK secara langsung meningkatkan total pembiayaan, namun tidak diikuti peningkatan jumlah pembiayaan PHR yang sebanding sehingga secara ratio turun.

Hasil penelitian ini serupa dengan penelitian yang dilakukan Kusumawati (2012) dengan objek penelitian sektor konstruksi dan Aprianti (2011) pada sektor pertanian. Hasil ini menunjukkan bahwa bank umum syariah (BUS) dan unit usaha syariah (UUS) belum memprioritaskan sektor pembiayaan produktif khususnya sektor PHR dalam penyaluran dan pendistribusian DPK. Hadist yang diriwayatkan oleh Ahmad, menyatakan bahwa pekerjaan yang paling baik adalah pekerjaan produktif dan yang paling diberkahi adalah perdagangan (jual beli) sehingga penyaluran DPK harus diberikan pada sektor riil khususnya sektor PHR.

\section{Guncangan pada Non Performing Financing (NPF)}

Guncangan Non Performing Financing direspon negatif pada periode pertama pada tingkat $0,01 \%$ yang terus mengalami penurunan sampai periode ke-21 yang selanjutnya stabil pada kisaran $0.18 \%$. Hasil ini menunjukkan hubungan negatif antara rasio 
pembiayaan sektor PHR dan NPF terjadi karena semakin tinggi pembiayaan bermasalah dari sektor PHR maka akan menyebabkan dana perbankan syariah menjadi tidak dapat berputar dari satu nasabah ke nasabah lain, karena terjadi kemacetan pada pembiayaan tersebut. Pembiayaan bermasalah yang tinggi menyebabkan bank harus membentuk cadangan penghapusan yang lebih besar. Hal ini juga dapat menurunkan minat bank syariah untuk menyalurkan pembiayaan pada sektor PHR dan mengalihkan untuk pembiayaan pada sektor lain dengan tingkat NPF yang lebih rendah.

Hasil penelitian ini sejalan dengan penelitian Nugroho (2009) dengan objek penelitian pembiayaan seluruh sektor pada perbankan syariah di Indonesia dan Kusumawati (2013) dengan objek sektor konstruksi. Prinsip kehati-hatian (prudent) memang diperlukan untuk mengantisipasi adanya moral hazard. Dalam Islam hal ini diatur bagi kedua pihak yang terlibat pembiayaan. Bagi nasabah atau pihak yang memiliki kewajiban melunasi, Islam mengatur agar akad uang dijalankan dipenuhi dengan baik dan jangan sampai menyisakan hutang (dalam al-Quran surat Al-Maidah ayat 1). Bagi bank atau pihak yang memberikan dana, Islam mengenal restrukturisasi dan memberikan kemudahan kepada debitur dalam membayar kewajibannya (dalam al-Quran surat Al-Baqarah ayat 280). Sehingga perbankan syariah dapat menekan kenaikan tingkat NPF dan menaikkan jumlah pembiayaan.

\subsection{Guncangan pada Kondisi Makro}

\section{Guncangan pada Tingkat Inflasi (INF)}

Guncangan pada tingkat inflasi direspon negatif pada periode pertama sebesar $0.001 \%$ yang kemudian stabil di periode ke-21 pada kisaran $0.018 \%$. Hasil ini menunjukkan jika terjadi kenaikan nilai inflasi maka rasio pembiayaan PHR akan turun. Penelitian ini sesuai dengan teori dikarenakan ketika tingkat inflasi meningkat maka harga barang akan meningkat yang mengakibatkan nilai input pada produsen membengkak diperparah oleh turunnya daya beli masyarakat sehingga kemampuan nasabah dalam melakukan kewajiban dalam pembiayaan akan berkurang. Peningkatan tingkat inflasi cenderung meningkatkan moral hazard yang berakibat pada kenaikan tingkat NPF pada sektor PHR. Tingkat inflasi yang meningkat akan memaksa pemerintah menggunakan kebijakan uang ketat (tight money policy) yang berarti pemerintah akan membatasi jumlah uang yang beredar antara lain dengan cara membatasi pemberian kredit dan pembiayaan. Ibnu Taimiyah (dalam Islahi 1988) menyatakan untuk mengurangi tingkat inflasi pemerintah harus mencetak uang sesuai dengan nilai yang adil atas transaksi masyarakat dan percetakan uang harus seimbang dengan transaksi pada sektor riil. Sehingga dana yang ada pada perbankan harus disalurkan pada sektor riil sehingga akan membantu menekan laju tingkat inflasi.

\subsection{Guncangan pada Instrumen Moneter}

\section{Guncangan pada Bonus Sertifikat Berharga Indonesia Syariah (SBIS)}

Guncangan pada bonus Sertifikat Berharga Indonesia Syariah direspon negatif di periode pertama pada tingkat $0.09 \%$ yang kemudian stabil di periode ke-19 pada kisaran $0.21 \%$. Hasil ini menunjukkan bahwa guncangan pada variabel SBIS direspon negatif oleh rasio pembiayaan PHR. Hal ini terjadi karena ketika bonus SBIS meningkat maka akan meningkatkan penempatan dana perbankan syariah dalam bentuk Sertifikat Bank Indonesia Syariah (SBIS) yang berakibat menurunnya penyaluran dana perbankan syariah pada pembiayaan sektor PHR. Hasil ini diperkuat Gambar 7 yang menunjukkan keadaan ratio pembiayaan sektor PHR dan tingkat bagi hasil SBIS. 


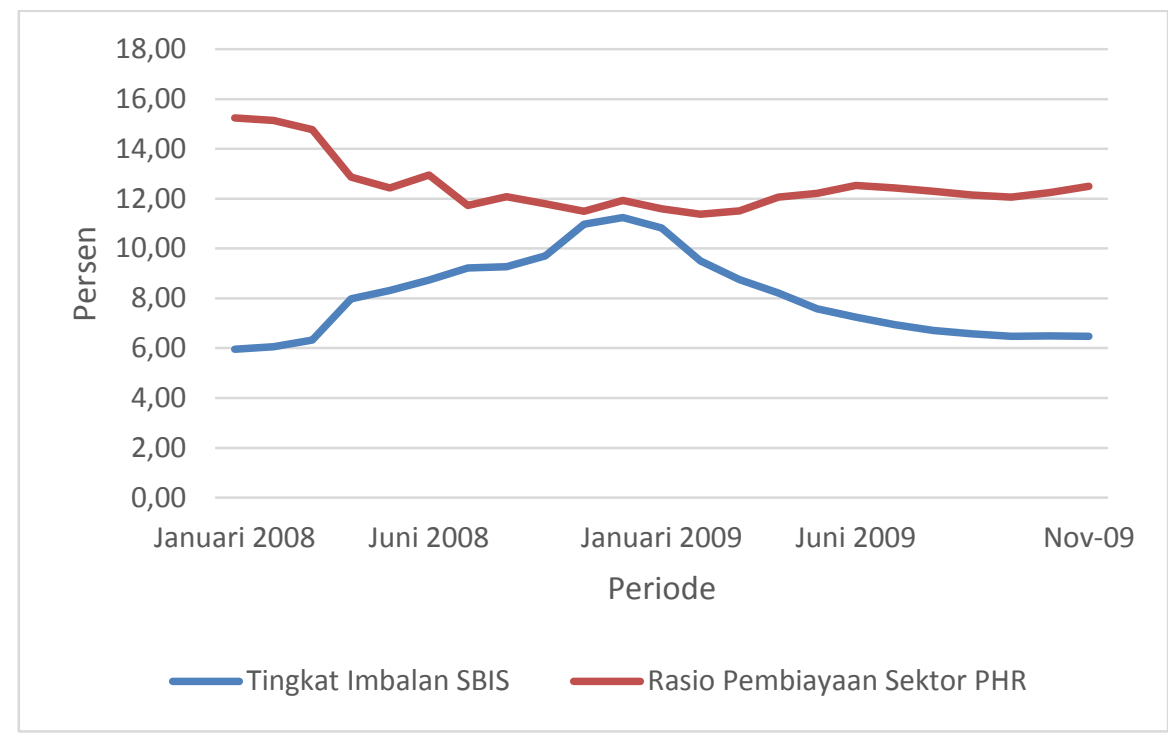

Sumber : Bank Indonesia (data diolah)

Gambar 7 Perkembangan Tingkat Imbalan SBIS dan Rasio Pembiayaan Sektor PHR

Gambar 7 menjelaskan bahwa ketika tingkat imbalan pada Sertifikat Bank Indonesia Syariah meningkatkan maka jumlah pembiayaan yang diberikan perbankan syariah pada sektor PHR akan menurun yang mengakibatkan menurunnya ratio pembiayaan perbankan syariah pada sektor PHR.

Dewan Nasional Syariah Majelis Ulama Indonesia (DSN-MUI) menjelaskan Sertifikat Bank Indonesia Syariah (SBIS) adalah surat berharga dalam mata uang rupiah yang diterbitkan oleh Bank Indonesia berjangka waktu pendek berdasarkan prinsip syariah, sebaiknya bank syariah memiliki SBIS untuk memanfaatkan dananya yang belum dapat disalurkan pada sektor rill. Dengan demikian SBIS bukanlah prioritas perbankan syariah dalam melaksanakan tugasnya sebagai lembaga perbankan melainkan menjadikan sektor rill sebagai fokus utama aktifitasnya. Hasil penelitian ini sejalan penelitian Kusumawati (2013) dengan objek sektor konstruksi.

\subsection{Guncangan Pada Return}

\section{Guncangan pada Equivalent Rate (ERP)}

Guncangan pada Equivalent Rate (ERP) direspon positif diperiode pertama pada tingkat $0.031 \%$ yang cenderung stabil diperiode ke- 47 pada tingkat $0.22 \%$. Guncangan pada ERP direspon secara permanen positif oleh rasio pembiayaan sektor PHR. Hal ini menunjukkan hubungan variabel ERP dengan PHR berbanding lurus dikarenakan ketika ERP mengalami peningkatan maka pendapatan perbankan syariah akan mengalami penambahan sehingga penyaluran dana untuk pembiayaan akan meningkat, termasuk untuk pembiayaan sektor PHR yang akan meningkatkan rasio pembiayaan sektor PHR. Hasil penelitian ini sejalan dengan penelitian Kusumawati (2013) dengan objek sektor konstruksi.

Guncangan Pada Suku Bunga Kredit (SBK) 
Guncangan pada Suku Bunga Kredit (SBK) direspon positif pada periode pertama pada tingkat $0.011 \%$ yang cenderung stabil diperiode ke-19 pada tingkat $0.13 \%$. Hal ini menunjukkan hubungan variabel SBK dengan PHR berbanding lurus. Ketika nilai suku bunga kredit naik maka tingkat bagi hasil pun akan naik karena ketika suku bunga kredit naik maka nasabah akan memilih perbankan syariah. Hal ini dikarenakan hubungan antara bank syariah dan konvensional seperti hubungan substitusi sehingga ketika suku bunga kredit perbankan konvensional naik maka akan menurunkan permintaan kredit pada perbankan konvensional yang kemudian akan meningkatkan ratio pembiayaan yang diberikan perbankan syariah pada sektor PHR.

\section{Variance Decomposition}

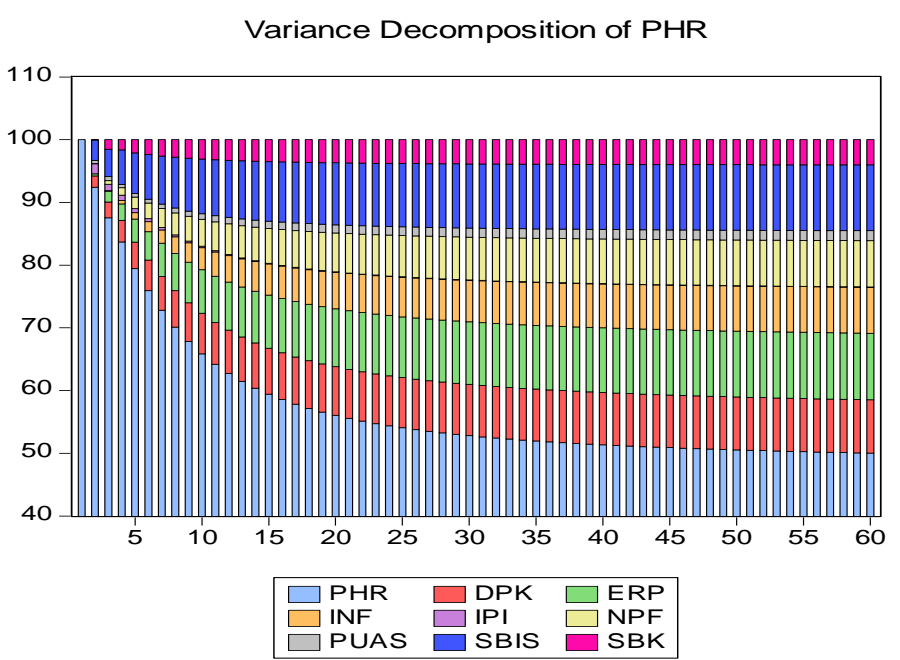

Gambar 8 Variance Decomposition

Variance Decomposition digunakan bertujuan untuk meneliti seberapa besar variabel memengaruhi variabilitas dari pembiayaan. Hasil dari variance decomposition terhadap rasio pembiayaan PHR menunjukkan fluktuasi pembiayaan PHR ditentukan oleh shock dari semua variabel dalam penelitian. Hasil menunjukkan bahwa pada periode pertama pembiayaan masih $100 \%$ dipengaruhi oleh pembiayaan itu sendiri.

Kemudian pada periode berikutnya tampak variabilitas rasio pembiayaan PHR mulai dijelaskan oleh variabel-variabel lainnya. Periode kedua menunjukkan pembiayaan masih dominan dipengaruhi oleh pembiayaan itu sendiri sebesar 92.40\%, DPK $1.80 \%$, ERP $0.35 \%$, INF $0.0026 \%$, IPI $1.59 \%$, NPF sebesar $0.04 \%$, PUAS $0.49 \%$, SBIS $3.25 \%$, dan SBK $0.047 \%$. Periode-Periode berikutnya menunjukkan penurunan pengaruh rasio pembiayaan PHR terhadap variabilitas itu sendiri dan terdapat peningkatan pengaruh dari variabel lainnya. Hingga akhirnya diperiode ke-60 kontribusi masing-masing variabel terhadap keragaman rasio pembiayaan PHR secara berurut dari yang terbesar hingga terkecil yaitu rasio pembiayaan PHR itu sendiri sebesar 50\%, ERP 10.61\%, SBIS 10.49\%, DPK $8.49 \%$, NPF 7.38\%, INF 7.33\%, SBK 4.01\%, PUAS $1.58 \%$, dan terkecil yaitu IPI sebesar $0.04 \%$. Secara keseluruhan, untuk analisis Forecasting Error Variance Decomposition (FEVD) menunjukkan bahwa selain pembiayaan PHR itu sendiri, variabel yang membentuk keragaman pada pembiayaan PHR dengan kontribusi paling besar dijelaskan oleh variabel Equivalent Rate (ERP), Bonus Sertifikat Berharga Indonesia Syariah (SBIS) dan Dana Pihak Ketiga (DPK). 


\section{Simpulan dan Saran}

\subsection{Simpulan}

Berdasarkan pemaparan hasil dan pembahasan dalam penelitian ini dapat ditarik beberapa kesimpulan, antara lain :

1. Ketika variabel DPK, NPF, SBIS, INF, dan PUAS mengalami keguncangan satu standar deviasi maka akan direspon secara negatif oleh rasio pembiayaan sektor PHR perbankan syariah. Sedangkan bila terjadi guncangan pada SBK, IPI, dan ERP sebesar satu standar deviasi maka akan direspon secara positif oleh rasio pembiayaan sektor PHR.

2. Variabel yang membentuk keragaman pada pembiayaan sektor perdagangan, hotel dan restoran (PHR) dengan kontribusi yang paling besar dijelaskan oleh variabel Equivalent Rate (ERP), Bonus Sertifikat Berharga Indonesia Syariah (SBIS), Dana Pihak Ketiga (DPK), Non Performing Financing (NPF), inflasi (INF), dan Suku Bunga Kredit (SBK).

\subsection{Saran}

1. Perbankan syariah harus meningkatkan jumlah DPK, mengurangi perputaran dan pada PUAS, dan mengurangi penempatan dana pada SBIS sehingga meningkatkan jumlah pembiayaan perbankan syariah pada sektor PHR.

2. Perbankan syariah harus mau melakukan restrukturisasi dan nasabah harus memenuhi kewajiban dalam akad sehingga tingkat gagal bayar bisa ditekan.

3. Penelitian selanjutnya dapat dilakukan dengan menambahkan variabel untuk setiap kategori faktor dan menambah periode pengamatan serta penambahan surat al-quran maupun al-hadist. Dapat pula dilakukan perbandingan antara perbankan syariah dan perbankan konvensional.

\section{Daftar Pustaka}

Al-Qur'an dan Terjemahannya, Departemen Agama RI, Jakarta: Bumi Restu.

Antonio MS. 2001. Bank Syariah dari Teori ke Praktik. Jakarta (ID): Gema Insani

Aprianti W. 2011. Analisis faktor faktor yang memengaruhi pembiayaan sektor pertanian pada perbankan syariah di Indonesia [skripsi]. Bogor (ID): Institut Pertanian Bogor.

Ascarya. 2002. Instrumen-instrumen Pengendalian Moneter. Jakarta (ID): Pusat Pendidikan dan Studi Kebanksentralan.

Ascarya. 2012. Alur transmisi dan efektivitas kebijakan moneter ganda di Indonesia. [jurnal]. Jakarta (ID): Buletin Ekonomi Moneter dan Perbankan Edisi Januari 2012

[BPS] Badan Pusat Statistik. 2014.Produk Domestik Bruto[Internet diunduh 2014 Maret 28]. Tersedia pada: http://bps.go.id.

[BI] Bank Indonesia. 2014. [Internet diunduh 2014 Maret 27]. Tersedia pada : http://www.bi.go.id.

Dewan Syariah Nasional. 2007. Sertifikat Bank Indonesia Syariah. Tersedia pada http://www.mui.or.id

Firdaus M. 2011. Aplikasi Ekonometrika Untuk Data Panel dan Time Series. Jakarta(ID): IPB Press

Ghafur M. 2007. Potret Perbankan Syariah Indonesia Terkini. Jakarta (ID): Biruni press.

Gujarati DN. 2006. Dasar-Dasar Ekonometrika. Jilid 1. Julius A Mulyadi, penerjemah. Jakarta (ID): Erlangga 
Huda N, Idris HR, Nasution EW, Wiliasih R. 2008. Ekonomi Makro Islam. Jakarta (ID): Kencana

Kasmir. 2002. Dasar-Dasar Perbankan. Jakarta(ID): PT. Raja Grafindo Persada.

Karim A. 2010. Bank Islam : Analisis Fiqh dan Keuangan (Edisi Keempat). Jakarta (ID): PT. Raja Grafindo Persada

Kementerian Keuangan Republik Indonesia. 2012. Tim kajian profil sektor riil: sektro perdagangan, hotel, dan restoran. Tersedia pada: http://www.kemenkeu.go.id

Mahkamah Agung Republik Indonesia. (2009). Kompilasi Hukum Ekonomi Syariah. Jakarta (ID): Kencana

Shihab, Quraish. Tafsir Al-Misbah, Pesan dan Keserasian Al-Quran. Jakarta:

Lentera Hati, 2002, Cet. Ke-XI

Kusumawati NN. 2013. Analisis Pembiayaan Sektor Konstruksi pada Perbankan Syariah di Indonesia. [jurnal]. Jakarta (ID): Al-Muzara'ah Jurnal Ekonomi Syariah Volume 1 Edisi 2 Tahun 2013.

Lipsey RG. 1995. Pengantar Makroekonomi. Jakarta (ID): Binarupa Aksara

Nugroho R. 2009. Analisis faktor-faktor penentu pembiayaan perbankan syariah di Indonesia: aplikasi model vector error correction [tesis]. Bogor (ID) Fakultas Ekonomi dan Manajemen, Institut Pertanian Bogor.

Soemitra A. 2010. Bank dan Lembaga Keuangan Syariah. Jakarta (ID): Kencana 2010.

Talavera O, Tsapin A, Zhould O. (2006). Macroeconomic uncertainty and bank lending : the case of Ukraince. Germany : German Institute for Economic Research, 637.

Wangsawidjaja Z. 2012. Pembiayaan Bank Syariah. Jakarta (ID): Penerbit Kompas Gramedia

Zahrah AM. 1994. Ushul Fiqh. Jakarta (ID): PT. Pustaka Firdaus 


\section{LAMPIRAN}

Lampiran 1 Hasil Estimasi VECM

Tabel Hasil Estimasi VECM

\begin{tabular}{lcc}
\hline \multirow{2}{*}{ Variabel } & \multicolumn{2}{c}{ Jangka Pendek } \\
\cline { 2 - 3 } CointEq1 & Koefisien & t-statistik \\
D(PHR(-1)) & $\mathbf{- 0 . 0 7 3 5 3 7}$ & {$[-\mathbf{1 . 6 6 5 0 5}]$} \\
D(DPK(-1)) & $\mathbf{- 0 . 4 5 7 6 6 0}$ & {$[-3.92566]$} \\
D(ERP(-1)) & -0.025297 & {$[-1.19008]$} \\
D(INF(-1)) & -0.000281 & {$[-0.00199]$} \\
D(IPI (-1)) & 0.189579 & {$[1.65000]$} \\
D(NPF(-1)) & -0.027925 & {$[1.62398]$} \\
D(PUAS(-1)) & 0.072145 & {$[0.41842]$} \\
D(SBIS(-1)) & 0.000580 & {$[0.61625]$} \\
D(SBK(-1)) & -0.245953 & {$[-1.62798]$} \\
& -0.070101 & {$[-0.37067]$} \\
D(DPK(-1)) & \multicolumn{2}{c}{ Jangka Panjang } \\
D(ERP(-1)) & $\mathbf{0 . 0 3 5 6 5 1}$ & {$[\mathbf{3 . 8 3 9 2 9}]$} \\
D(INF(-1)) & $\mathbf{- 0 . 7 2 1 9 2 2}$ & {$[-4.84221]$} \\
D(IPI $(-1))$ & $\mathbf{1 . 8 0 2 4 4 4}$ & {$[-1.51005]$} \\
D(NPF(-1)) & -0.039224 & {$[\mathbf{2 . 0 3 4 1 6}]$} \\
D(PUAS(-1)) & $\mathbf{0 . 9 3 6 2 4 7}$ & {$[-1.33265]$} \\
D(SBIS(-1)) & -0.003819 & {$[\mathbf{2 . 1 6 2 0 0 ]}$} \\
D(SBK(-1)) & $\mathbf{0 . 3 3 0 2 9 0}$ & {$[-5.28158]$} \\
\hline
\end{tabular}



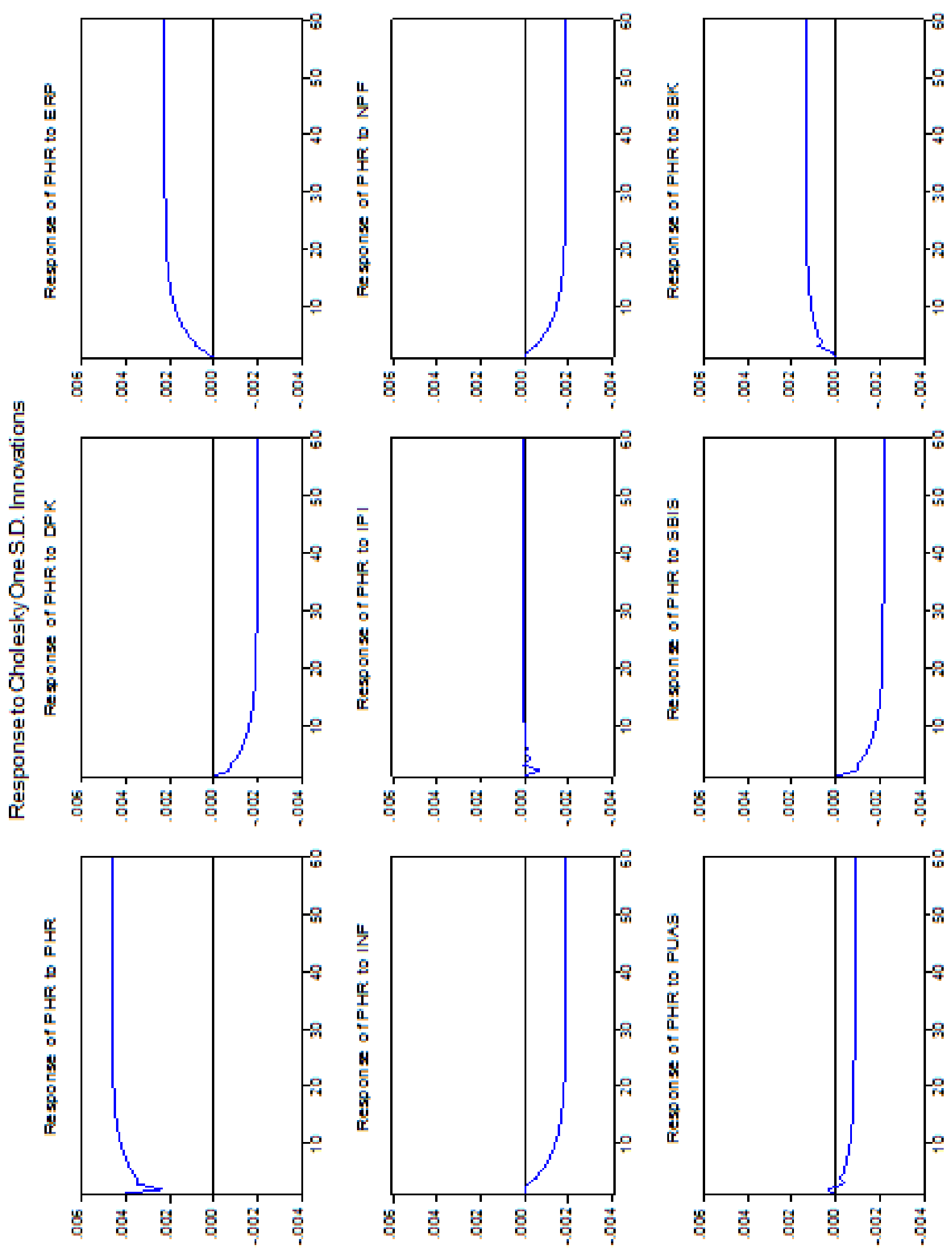

Jurnal Al-Muzara'ah, Vol. 2, No. 2

(ISSN p: 2337-6333; e: 2355-4363) 